\title{
Impacts of Aerosol Particle Size Distribution and Land Cover Land Use on Precipitation in a Coastal Urban Environment Using a Cloud-Resolving Mesoscale Model
}

\author{
Nathan Hosannah and Jorge E. Gonzalez \\ Department of Mechanical Engineering, The City College of New York, New York, NY 10031, USA \\ Correspondence should be addressed to Nathan Hosannah; nhosannah@gmail.com
}

Received 22 July 2013; Revised 22 September 2013; Accepted 1 December 2013; Published 14 January 2014

Academic Editor: George A. Isaac

Copyright (C) 2014 N. Hosannah and J. E. Gonzalez. This is an open access article distributed under the Creative Commons Attribution License, which permits unrestricted use, distribution, and reproduction in any medium, provided the original work is properly cited.

\begin{abstract}
Urban environments influence precipitation formation via response to dynamic effects, while aerosols are intrinsically necessary for rainfall formation; however, the partial contributions of each on urban coastal precipitation are not yet known. Here, the authors use aerosol particle size distributions derived from the NASA aerosol robotic network (AERONET) to estimate submicron cloud condensation nuclei (CCN) and supermicron CCN (GCCN) for ingestion in the regional atmospheric modeling system (RAMS). High resolution land data from the National Land Cover Database (NLCD) were assimilated into RAMS to provide modern land cover and land use (LCLU). The first two of eight total simulations were month long runs for July 2007, one with constant PSD values and the second with AERONET PSDs updated at times consistent with observations. The third and fourth runs mirrored the first two simulations for "No City" LCLU. Four more runs addressed a one-day precipitation event under City and No City LCLU, and two different PSD conditions. Results suggest that LCLU provides the dominant forcing for urban precipitation, affecting precipitation rates, rainfall amounts, and spatial precipitation patterns. PSD then acts to modify cloud physics. Also, precipitation forecasting was significantly improved under observed PSD and current LCLU conditions.
\end{abstract}

\section{Introduction}

Many studies present clear evidence that cities influence regional weather via modification of synoptic fronts, urban heat island (UHI) generation [1-6], surface-atmosphere interactions that impact surface heat and moisture fluxes [7], building barrier effects [8], and increased aerosol concentrations [9]. Sinha Ray and Srivastava [10] showed that the rapidly urbanizing Indian landscape experienced precipitation increases in several urban locations $(>70 \mathrm{~mm} /$ day $)$ during the summer monsoon season over the last 100 years, coincident with an increase in extreme rainfall frequency (>120 mm/day). Analysis of historical precipitation records for Phoenix, AZ, revealed statistically significant increases in mean precipitation of $12-14 \%$ during the monsoon season from a preurban (1895-1949) to posturban (1950-2003) period in suburbs northeast of the Phoenix metropolitan area [11]. Selover [12] showed that moving summer convective storms over Phoenix produced precipitation minimums over the city in conjunction with maximums in surrounding lateral and downwind locations.

Shepherd et al. [13] showed that UHIs affect local and regional weather/temperature via increased energy demands for cooling, adjustment of local wind flows due to a nonuniform thermal state, air quality deterioration, and modifications to the precipitation cycle. Data from the Tropical Rainfall Measuring Mission was investigated to identify warmseason rainfall patterns around Atlanta, Montgomery, AL; Nashville, TN; San Antonio, Waco, and Dallas from 1998 to 2000. Results showed precipitation increases of up to $51 \%$ in these cities over their surrounding rural areas. In addition to the dynamic effects of urban areas on precipitation, aerosols near the surface can be transported into the atmosphere via convection (which is stronger over the city when a UHI is present), enabling them to act as cloud condensation 
nuclei (CCN) and giant CCN (GCCN) that may also modify precipitation totals, rates, and spatial patterns.

Bornstein and LeRoy [8] showed that building-barrier induced precipitation difluence during non-UHI periods. The upwind urban edge divides regional flows as they approach a city, especially during stable nocturnal conditions. Difluence produces cyclonic turning over the left-hand urban edge (looking downstream) and anticyclonic turning over the right-hand urban edge. Barriers also produce confluence at both lateral urban edges, where air deflected around the city converges with the undisturbed prevailing flow, and downwind of the city where the flow reunites. Investigation of a storm that took place on August 5, 1977, revealed splitting over NYC. Level 1 and 3 radar echoes (which represent precipitated water) split and traveled around the city, while the level 1 echoes (which represent water vapor) did not split.

Niyogi et al. [14] examined 91 unique summertime (May 2000-August 2009) thunderstorm cases over the Indianapolis urban area and found that land surface heterogeneity modified the intensity and composition/structure of approaching thunderstorms. Over $60 \%$ of storms changed structure over Indianapolis compared with only $25 \%$ over surrounding rural areas, showing that the urban area has a strong climatological influence on regional thunderstorms. In addition to the climatological study, a case study of a typical storm on June 13, 2005, using available observations and the fifth-generation Pennsylvania State University-NCAR Mesoscale Model (MM5), version 3.7.2, showed that removal of the Indianapolis urban region caused distinct differences in regional convergence and convection as well as in simulated base reflectivity, surface energy balance, and boundary layer structure.

To fully understand the nature of precipitation in urban environments it is important that the role of aerosols also be considered. Aerosols can change the frequency of cloud occurrence, cloud thickness, and rainfall amounts. At the large scale, aerosols alter evaporation rates of oceans by modifying the transmission and absorption of solar energy to the water $[15,16]$. This is an indirect effect. At the small scale, aerosols become CCN/GCCN. In urban environments, where anthropogenic CCN from pollution are abundant, cloud microphysical processes including condensation, evaporation, collision, coalescence, and droplet breakup are modified, impacting regional precipitation and surface processes by modifying surface sensible and latent heat fluxes [17]. Droplets that form on GCCN such as sea salt can accelerate autoconversion, while droplets that form on the smaller CCN reduce autoconversion rates and result in suppressed precipitation, enhanced cloud mass fluxes, a colder and drier boundary layer, larger surface fluxes, a warmer and more humid atmosphere, and a lower convective available potential energy [18].

Aerosols generated in urban and industrial sites have been shown to impact precipitation in South Asian atmospheric brown clouds [19], smoke clouds over the island of Borneo [15], warm and cold weather clouds [16], cold clouds over mountains [20], shallow orographic clouds [21], clouds near the front range of the Rocky Mountains [22], and convective clouds over and downwind of St. Louis [23].
Difficult to pin down, aerosol effects on precipitation range from enhancement to suppression. High aerosol concentrations in winter orographic clouds (polluted) have been found to yield more cloud water, but less rainwater than clouds with low aerosol concentrations [24]. Increased CCN concentration may reduce autoconversion rates since smaller particles do not coalesce as efficiently as do the larger GCCN and must compete for the available liquid water content. If the smaller droplets ascend above the freezing level, there can be precipitation enhancement due to dynamic invigoration, the prolific generation of frozen droplets [9]. This is how hail and graupel may be formed in temperate continental summer storms.

Aerosols from urban and industrial air pollution have also been shown to suppress rain and snow, as precipitation losses over topographical barriers downwind of major coastal urban areas in California and Israel were reported to account for $15-25 \%$ of annual precipitation over these regions [21]. Furthermore, varying aerosol PSD can also impact cloud microphysical processes. Comarazamy et al. [25] showed that variation of aerosol PSD can impact precipitation totals and patterns in the Island of Puerto Rico. They found that increasing GCCN concentration enhanced total accumulated precipitation while simultaneously increasing both $\mathrm{CCN}$ and GCCN concentrations suppressed rainfall.

Therefore, precipitation formation involves contributions from large scale forcing and from local urban effects and modification of cloud microphysics due to aerosol ingestion from urban sources. Urban effects on precipitation may be synthesized as based on the hypotheses of Bornstein et al. (2011, personal communication) that suggests that wind, the urban heat island, convergence, and or divergence primarily affects storm formation and path, while aerosol ingestion impacts storms after dynamic effects have set the stage for precipitation to occur via modification of cloud microphysics.

Where previous studies have shown the importance of aerosol concentration and dynamic effects on rainfall over cities, the present study aims to go further in depth by investigating variation of observed PSD and land cover land use (LCLU) in precipitation events at high horizontal resolutions (e.g., $1 \mathrm{~km}$ ) in NYC. Advancing the present state of weather prediction and analysis requires the ingestion of observed aerosol information. The present research aims to determine whether precipitation results may be improved with ingestion of aerosol PSD data from the aerosol robotic network (AERONET) and assimilation of LCLU data from the National Land Cover Database (NLCD). The present work lends support to the argument that ingestion of aerosol PSD data in numerical models is important in climate modeling and weather prediction and that its study can lead to advancements in the use of data from updated algorithms that run satellite weather instruments, LIDAR, and other remote sensing technologies.

\section{Data and Methodology}

2.1. Synoptic Overview. Figure 1 shows total precipitation data attained from National Weather Service (NWS) sites 


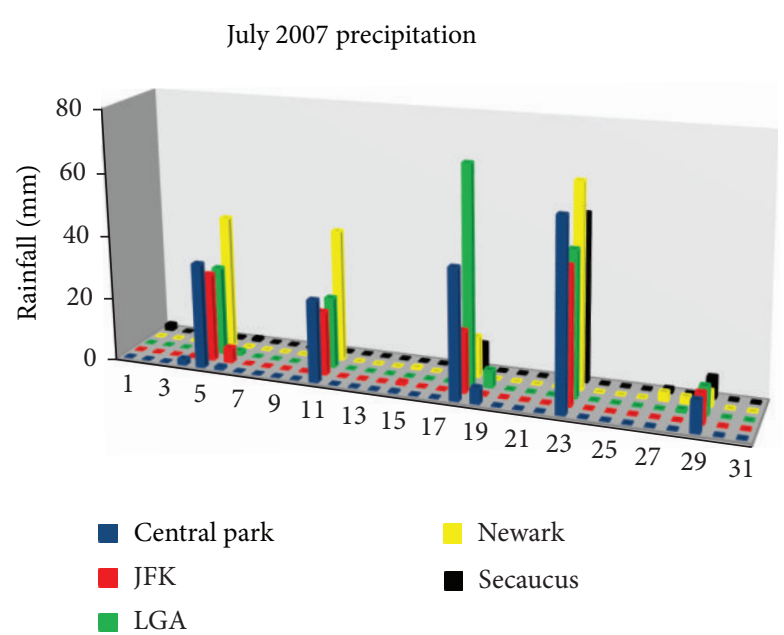

FIGURE 1: National Weather Service (NWS) data for various sites in the NYC/NJ region for July 2007.

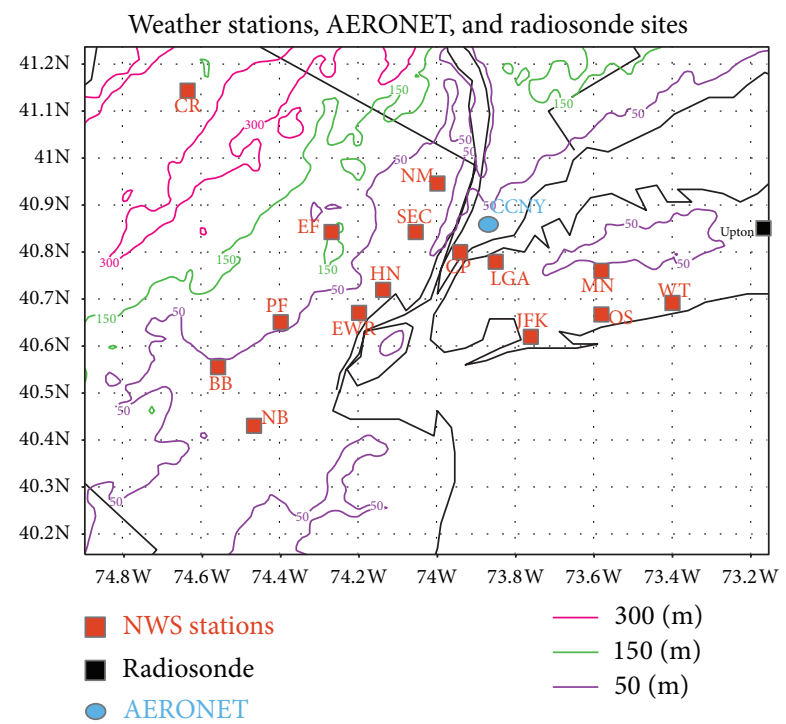

FIGURE 2: Data sites over topography. NWS surface stations are shown as red squares, the Upton radiosonde site is shown as a black square, and the CCNY AERONET site is shown as a light blue circle.

over NYC/New Jersey (NJ) for July 5, 11, 18, 23, and 29 2007. The July 11, 2007, event was selected for case analysis because it is a localized storm with high rainfall variability across the region. Surface pressure maps over NYC show that rainfall on 11 July 2007 was not due to major synoptic influences or direct frontal movement. Instead, high pressure southeast of NYC and a north to south low pressure trough through the city produces an observed southeasterly onshore flow. The CAPE value on at 0000 UTC on July 11, 2007, (2000 EDT on the 10th), was $890 \mathrm{~J} \mathrm{~kg}^{-1}$ due to its relatively warm air. In the dry layer up to $300 \mathrm{hPa}$ (above a surface saturated layer), dew point temperatures are significantly lower than air temperature values. Any CAPE value over $0 \mathrm{~J} \mathrm{~kg}^{-1}$ suggests the possibility of local convective influences.

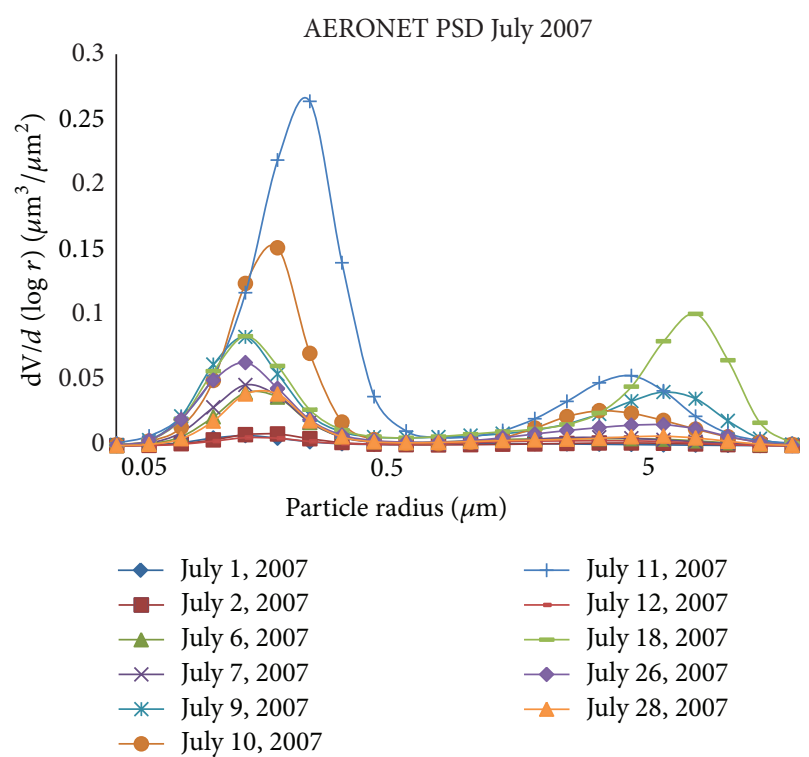

FIGURE 3: PSD over CCNY AERONET station (40.83N, 73.94W) for July 2007.

For this research, all analyses were performed on 16 sites. Figure 2 shows the locations of 16 National Weather Service sites used for analysis, the Upton, NY, radiosonde site, and the CCNY AERONET site over topography of the region.

2.2. Data. AERONET is a network of ground-based sunphotometers that measure sunlight intensity and can retrieve spectral aerosol optical depth, precipitable water, and PSD in diverse aerosol regimes. All products represent an average of the total aerosol column within the atmosphere. PSD may change from day to day over NYC, as chronicled by AERONET data for July 2007 displayed in Figure 3. Aerosol PSDs are retrieved from AERONET measurements via an inversion algorithm [26, 27]. For this study, AERONET PSDs were converted from distributions to number concentrations for ingestion in RAMS via the following equation:

$$
\frac{d V}{d(\log r)}=V(r) * \frac{d N}{d(\log r)},
$$

where

$$
\frac{d N}{d(\log r)}
$$

is the density number log-normal distribution needed in RAMS, and

$$
\frac{d V}{d(\log r)}
$$

is the volume distribution obtained from AERONET for each radius $(r)$. The volume of each CCN/GCCN (assumed spherical) is

$$
V(r)=\frac{4 \pi}{3} * r^{3}
$$


such that

$$
\frac{d N}{d(\log r)}=\frac{3}{4 \pi r^{3}} * \frac{d V}{d(\log r)}
$$

This implies that all particles are considered spherical in geometry. PSD retrievals were cloud-screened as specified by Holben et al. [28]. The AERONET algorithm determines the percentage of spherical particles required to give the best fit to the measured spectral sky radiance angular distribution [29]. Comparisons of size distributions between in situ and AERONET retrievals for biomass burning in South America, Southern Africa, and North America showed that the volume median diameters of the in situ versus the AERONET retrievals were often within $\sim 0.01 \mu \mathrm{m}$ of each other for all three regions [30]. It should be noted that there is uncertainty in the details of the PSD inversion that forces a simple modal fit. Also, smoke particles are of a different type than those over NYC. Biomass aerosol tends to be relatively unimodal and almost all of the particles are large enough in size to be good light scatterers; both are properties which enhance the retrieval. Urban areas consist of broader distributions, and particles smaller than $0.1 \mu \mathrm{m}$ radius are very hard to determine from such optical methods. It is for this reason that the present work focuses on fine mode particles between 0.1 and $1 \mu \mathrm{m}$ radius and coarse mode particles above $1 \mu \mathrm{m}$ radius.

For this paper, PSD is classified as high volume fine mode (HVFM) or high volume coarse mode (HVCM). PSDs characterized as high volume have volume distribution values of $0.1 \mu \mathrm{m}^{3} \mu \mathrm{m}^{-2}$ or greater for either the fine or coarse mode modal radii. PSDs obtained for July 11, 2007, (HVFM), and July 18, 2007, (HVCM), over NYC have similar modal radii values to those obtained for other sites in the Northeastern United States, for example, Cartel, Vermont, and the Maryland Science Center although aerosol concentration over Cartel is less than half the concentration over the City College of New York (CCNY). This increased concentration over NYC is theorized to be an impact of the ingestion of urban aerosols from NYC. For this study, only PSD data from the CCNY site was used for ingestion into RAMS. Although there is a decrease in aerosol volume moving outward from the center of NYC, this is not a major issue for the current research because analyses are performed on the small domains in and around NYC.

LCLU data was obtained from the National Land Cover Database (NLCD 2006). Shown in Figure 4, NLCD is a multiclass land cover classification scheme that has been applied consistently across the conterminous US at a spatial resolution of $30 \mathrm{~m}$. NLCD (2006) is based on the classification of Landsat Enhanced Thematic Mapper+ (ETM+) circa 2006 satellite data [31] and serves as the definitive land cover database for US. There are 20 NLCD land classes, including three for urban areas. Each land class has values for albedo, surface roughness, percent impervious surface, and percent tree canopy cover characteristic of its type. The classes and their descriptions are tabulated in the supplement to this paper (see Supplementary Material available online at http://dx.doi.org/10.1155/2014/904571).
NLCD land cover over the NYC region

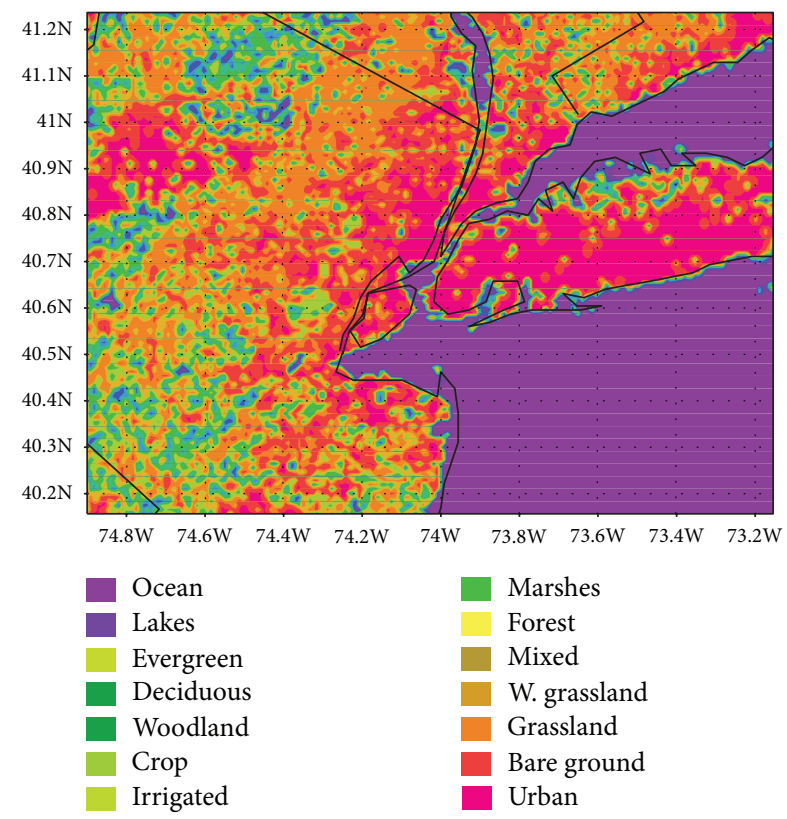

FIgURE 4: RAMS land classes over the NYC/NJ Region (Grid 3).

2.3. Model Configuration and Experimental Setup. RAMS is the main research tool for the present study as it allows modification of LCLU and microphysical parameters which include aerosol PSD, particle concentration, and particle size $[32,33]$. Surface processes were parameterized using the land ecosystem-atmosphere feedback model (LEAF-3, [34]). LEAF-3 is a submodel of RAMS that evaluates energy and water budgets at the surface of the Earth. LEAF-3 assimilates physical characteristics of vegetation, soil, lakes, oceans, and snow cover and their influence on each other and on the atmosphere. The model incorporates prognostic equations for soil temperature and moisture for multiple layers, vegetation temperature and surface water including dew and intercepted rainfall, snow cover mass and thermal energy for multiple layers, and temperature and water vapor mixing ratio of canopy air. Exchange terms in these prognostic equations include turbulent exchange, heat conduction to and from the soil, water diffusion and percolation in the snow cover and soil, longwave and shortwave radiative transfer, transpiration, and precipitation. There are 30 different land surface types included within LEAF-3 (found in supplement to this paper), defined in the biosphere-atmosphere transfer Scheme [35]. Multiple vegetation patches may be activated within each grid to represent the variation in surface vegetation. For urban regions, leaf-area index and vegetation fractional coverage are minimized while roughness length is increased, thereby representing the effects of the rough city surface.

In addition to land cover modification, RAMS also facilitates ingestion of bimodal PSDs that often appear in nature $[36,37]$. The two-moment microphysical scheme employs lookup tables of autoconversion rates generated from bin model computations based on assumed distribution 
July 2007 RMSE (daily precipitation)

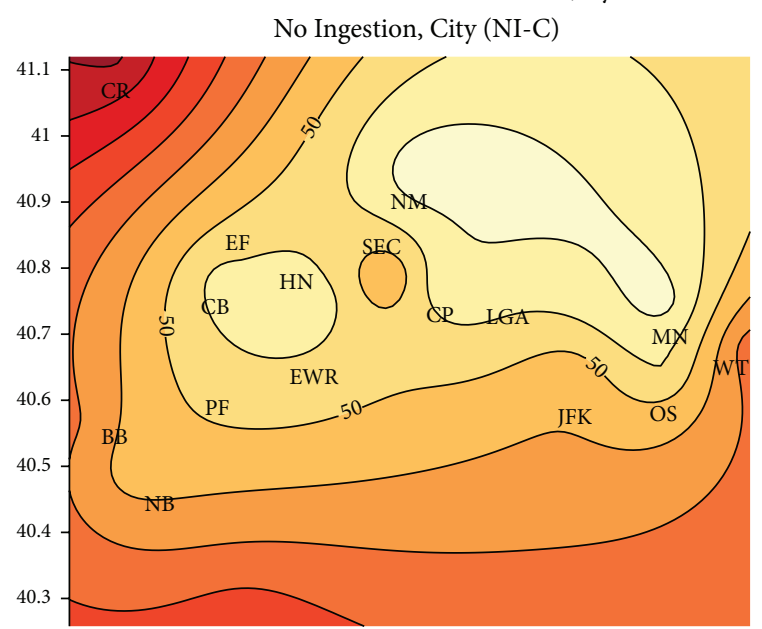

No Ingestion, No City (NI-NC)

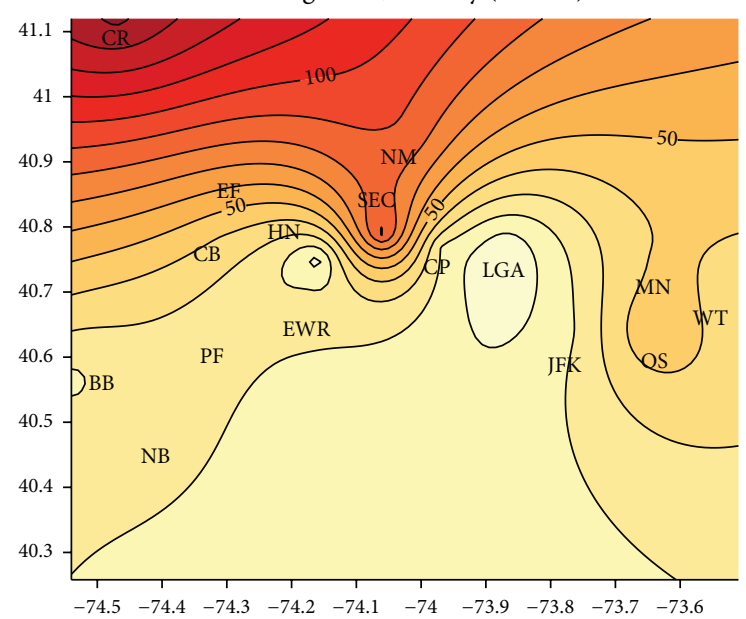

Ingestion, City (I-C)

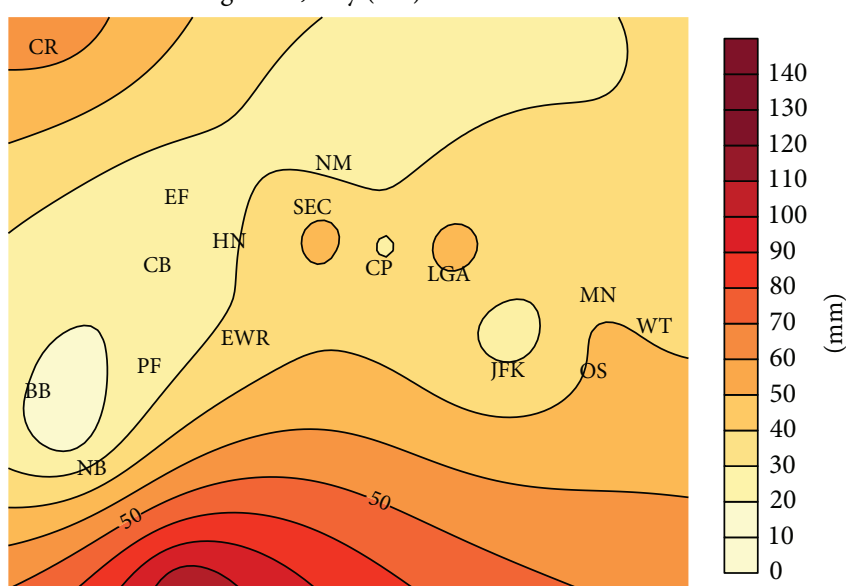

Ingestion, No City (I-NC)

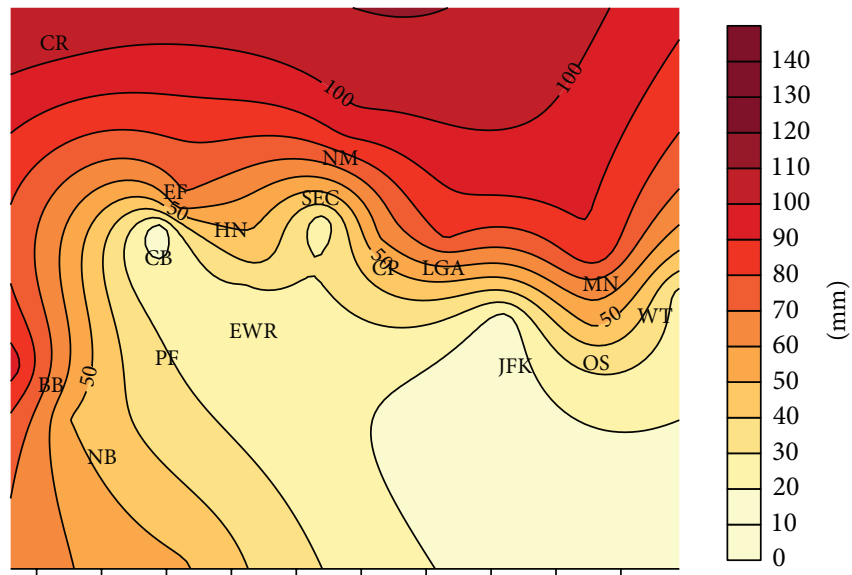

(a)

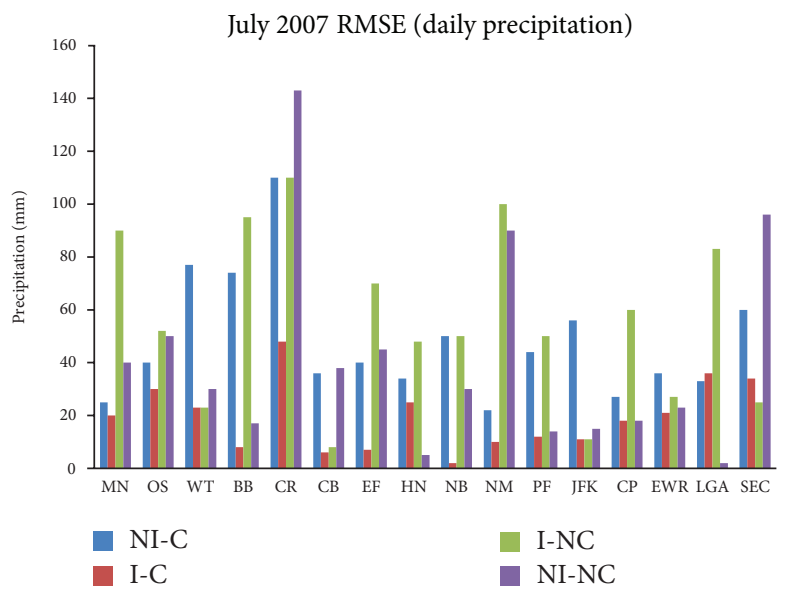

(b)

FIgURE 5: Accumulated daily precipitation RMSE for all monthly cases. The bar graph (b) is representative of actual RMSE values for NI-C (blue), I-C (red), I-NC (green), and NI-NC (purple) over 16 sites. The spatial plots (a) are attained via interpolation of error at the closest grid point to the model errors. 


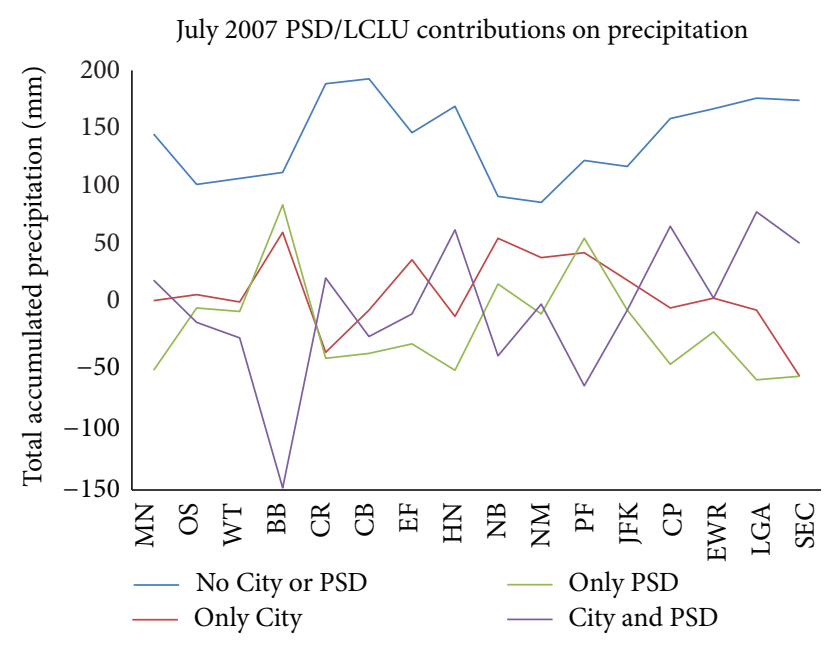

FIGURE 6: PSD/LCLU individual contributions on precipitation.

functions. Microphysical processes represented include cloud droplet nucleation (one or two modes), ice nucleation, vapor deposition, evaporation, sublimation, heat diffusion, freezing/melting, shedding, collision and coalescence, and secondary ice production. There are 8 hydrometeor categories, which include cloud droplets, rain, ice, snow, aggregates, graupel, hail, and drizzle. Each hydrometeor category may grow independently from vapor and self-collection or may interact with other categories via collision and coalescence [38].

CCN/GCCN are allowed to deplete upon nucleation/ activation and to replenish upon evaporation. From this information, CCN/GCCN masses are calculated from lookup tables [39]. Simulations with zero PSD updates were assigned constant CCN and GCCN concentrations of $300 \mathrm{~cm}^{-3}$ and $20 \mathrm{~cm}^{-3}$, respectively, as these values represent modal data averages for the month of July 2007. Simulations with ingested observed PSD updates were modified as data was available, amounting to 11 updates during July 2007. Each update required the simulation to be stopped at the time of ingestion. Modal CCN and GCCN concentrations and particle sizes were then amended in the microphysics module, and the simulation was continued via history restart.

Simulations for this study incorporate three nested grids, the largest at $16 \mathrm{~km}$ horizontal grid spacing, the second at $4 \mathrm{~km}$ horizontal grid spacing, and the finest grid at $1 \mathrm{~km}$ horizontal grid spacing. All three grids are centered at $40.8 \mathrm{~N}$, 74W. Grid 1 covers the northeast US, grids 2 and 3 cover NYC, western NJ, and Long Island and allow for high resolution analysis of the NYC/NJ area. LCLU data from NLCD (2006) was assimilated onto RAMS grids in order to characterize "City" and "No City" cases. For "No City" simulations, urban grid cells were transformed into deciduous broadleaf forest grid cells (Figure 4). Topography and geographical barriers are not modified in any of the simulations. National Center for Environmental Prediction (NCEP) pressure reanalysis data at $2.5^{\circ} \times 2.5^{\circ}$ resolution is assimilated to provide initial and boundary conditions, with boundary conditions updated every 6 hours. PSD from the AERONET sunphotometer network was processed and ingested directly into RAMS following the approach of Comarazamy et al. [25]. For July 2007, there are 11 updates, as shown previously in Figure 3. The complete assimilation/ingestion plan is included in the supplement.

The ensemble of experiments is displayed in Table 1. Four simulations were month long runs for July 2007, the first with constant PSD values (No Ingestion-City, NI-C) and the second with PSD updates as they became available in the AERONET dataset (Ingestion-City, I-C). The third and fourth simulations mirrored the first two simulations for a "No City" LCLU (No Ingestion-No City, NI-NC, and Ingestion-No City, I-NC). Four more simulations addressed a one day localized precipitation event under City and No-City conditions, respectively.

Run 1 is the July 11, 2007, precipitation event with the PSD observed above the CCNY AERONET site assimilated into the model for the same date and with City LCLU. Run 2 is the July 11, 2007, precipitation event assimilated with July 18, 2007, PSD data with City LCLU. The July 11, 2007, HVFM PSD will likely suppress precipitation, while the July 18, 2007, HVCM PSD should enhance accumulated precipitation totals. These PSD effects are attributed to hastened/reduced rates of autoconversion due to the presence of higher volumes of GCCN/CCN (reduced GCCN number concentration can result in increased GCCN volume when the modal radius is large as is the case in July 18, 2007). Run 3 is the July 11 , 2007, precipitation event with PSD data for the same date and No City LCLU. Run 4 is the July 11, 2007, precipitation event ingested with July 18, 2007, PSD and No City LCLU. Each daily run endured for 24 hours. Test runs showed that spin up beyond 12 hours had no noticeable impact on model results.

\section{Results and Discussion}

3.1. July 2007 Monthly Cases. In order to prove that incorporation of PSD/LCLU data from AERONET/NLCD improves precipitation estimates, monthly runs with and without observed PSD ingested and current City LCLU were compared against runs with No City LCLU. Results presented in Table 2 show improved total precipitation estimation with updated PSD and current LCLU (I-C) for 11 of 16 sites. Over NYC (CP 40.80N/73.90W) and the four closest sites (JFK 40.65N/73.78W, LGA 40.78N/73.87W, SEC 40.78N/74.07N, and EWR $40.73 \mathrm{~N} / 74.18 \mathrm{~W}$ ), monthly precipitation errors range from 0.03 to $3.1 \%$ compared to $2.5-21.7 \%$ when PSD is not updated over No City LCLU. Positive/negative biases are indicated by the italic and bold font.

Simulation NI-C over-predicts total accumulated precipitation for eight of 16 sites, while I-C overpredicts at five of 16 sites, suggesting that the presence of the city can suppress precipitation. NI-C produces more rainfall than I$\mathrm{C}$ for 10 of 16 sites. These results are statistically significant to a $99.7 \%$ confidence level. Accuracy of total precipitation compared with observations is reduced for the I-NC and NI-NC scenarios. For 11 of 16 sites, the I-C scenario more accurately predicts observed precipitation totals than all other month long simulations. All runs captured the five 
July 11, 2007, temperature
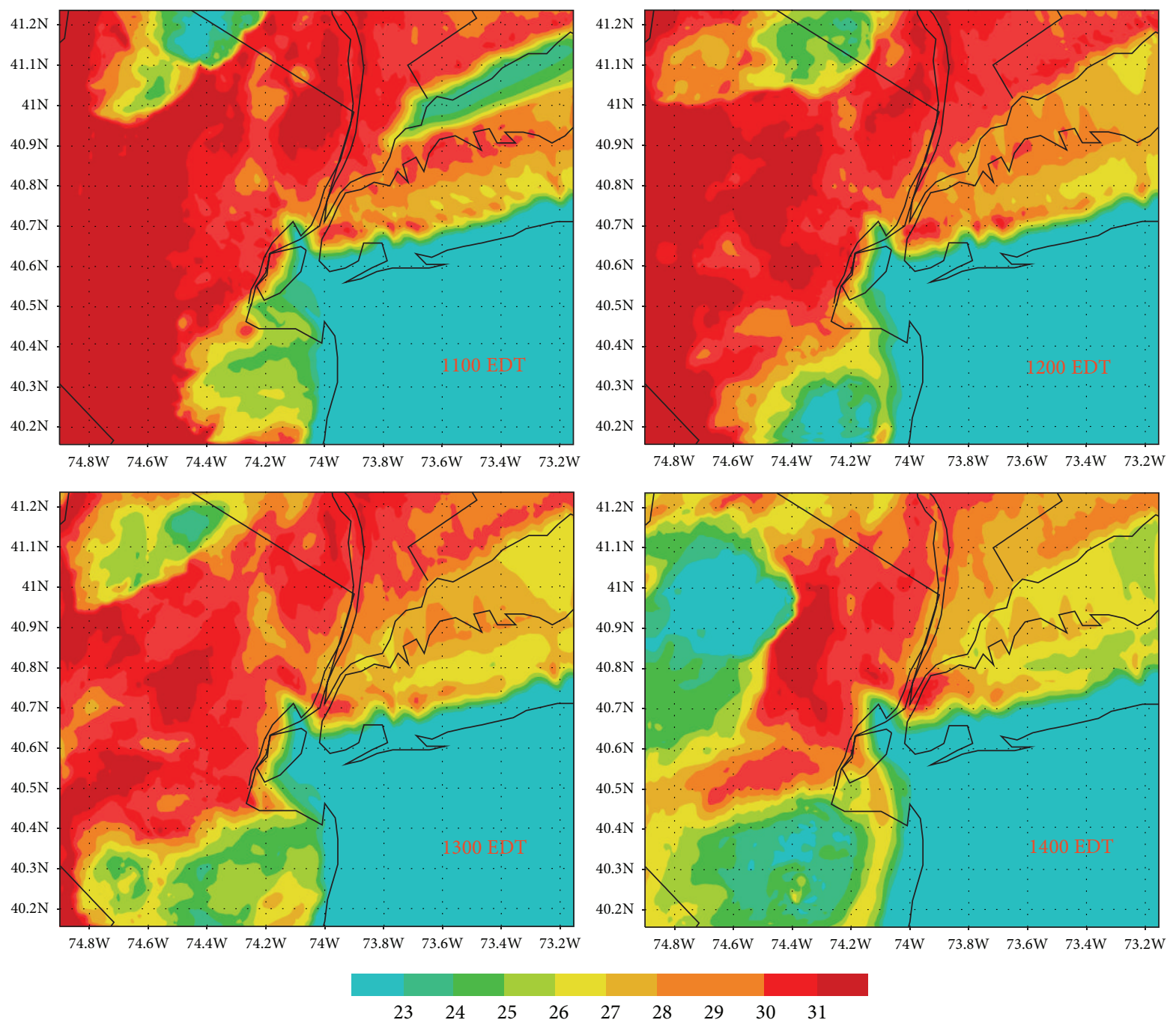

$\left({ }^{\circ} \mathrm{C}\right)$

FIGURE 7: Temperature over the NYC region $2 \mathrm{~m}$ from the surface at different local standard times.

precipitation events of July 2007 within 12 hours of their onset, consistent with findings by Comarazamy et al. [25]. Root mean square error (RMSE) plots in Figure 5 show that simulation I-C is a better predictor than all other month-long simulations. Removal of the city (NI-NC and I-NC) increases errors over Manhattan, which is expected since Manhattan is highly urbanized. When the city is present but PSD is not updated with observed values (NI-C), errors are higher than the I-C case, but far less than the No City cases.

Using the method of factor separation [40], it is possible to determine the individual contributions of PSD and LCLU on precipitation. For $n$ number of factors (two in this case), $2^{n}$ simulations are necessary (at least four in this case). For each location, the contributions for each of the four conditions (I-C, NI-C, NI-NC, and I-NC) are calculated. The sum of the four conditions at a given location equals the observed precipitation total. For July 2007 monthly simulations over 16 sites (Figure 6), results show that NI-NC weighs heaviest on precipitation results (nearly twofold over I-C, with an average of $103 \%$ increase). I-NC has the second highest impact on precipitation, with nine of 16 sites showing increases (average of $7 \%$ over all sites). Lastly, NI-C shows increases at five of 16 locations (average of $18 \%$ over all sites). Note that the increased impact is due to larger precipitation totals for No City cases over City cases in 10 of 16 sites, whether the observed precipitation is over/underpredicted. These results support the suggestion that land use is dominant in impacting precipitation over and near NYC, with PSD modification effects being secondary, but also important in producing rainfall.

3.2. July 11, 2007, Daily Cases. Run 1 is used to determine how well the model captures observed precipitation 
11 July, 2007, precipitation rate
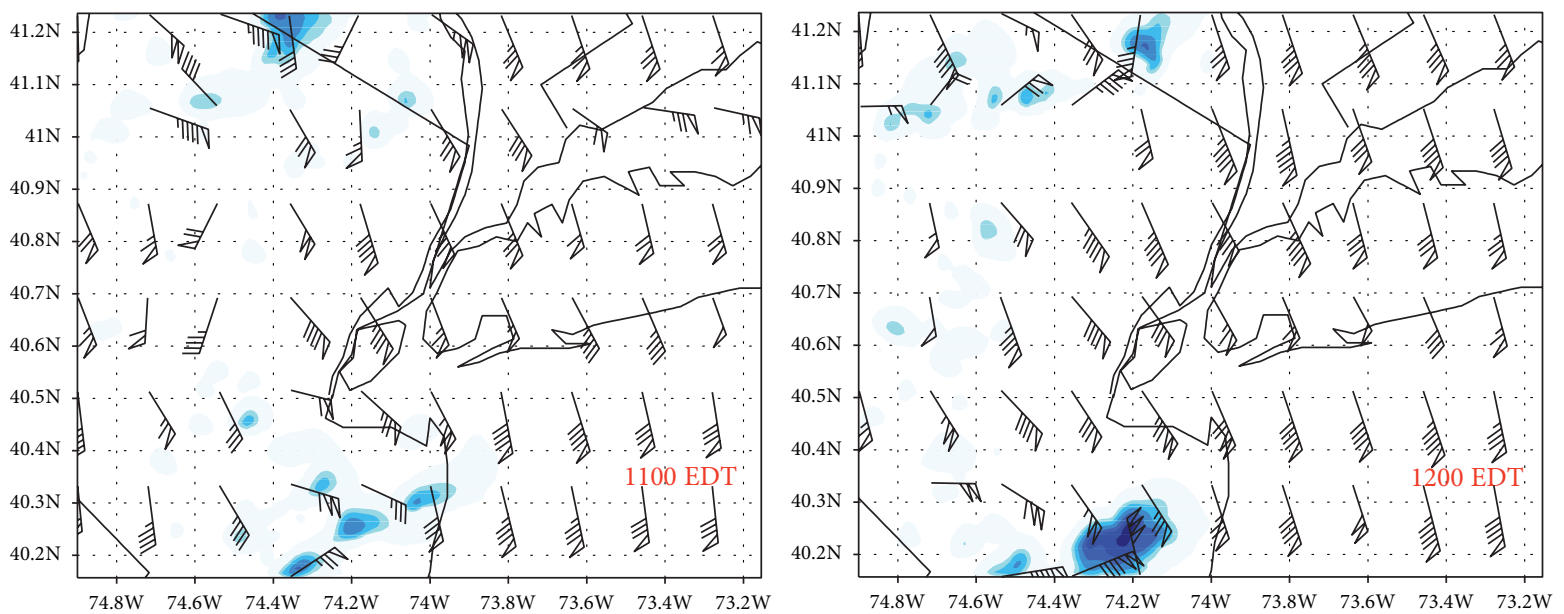

(a)
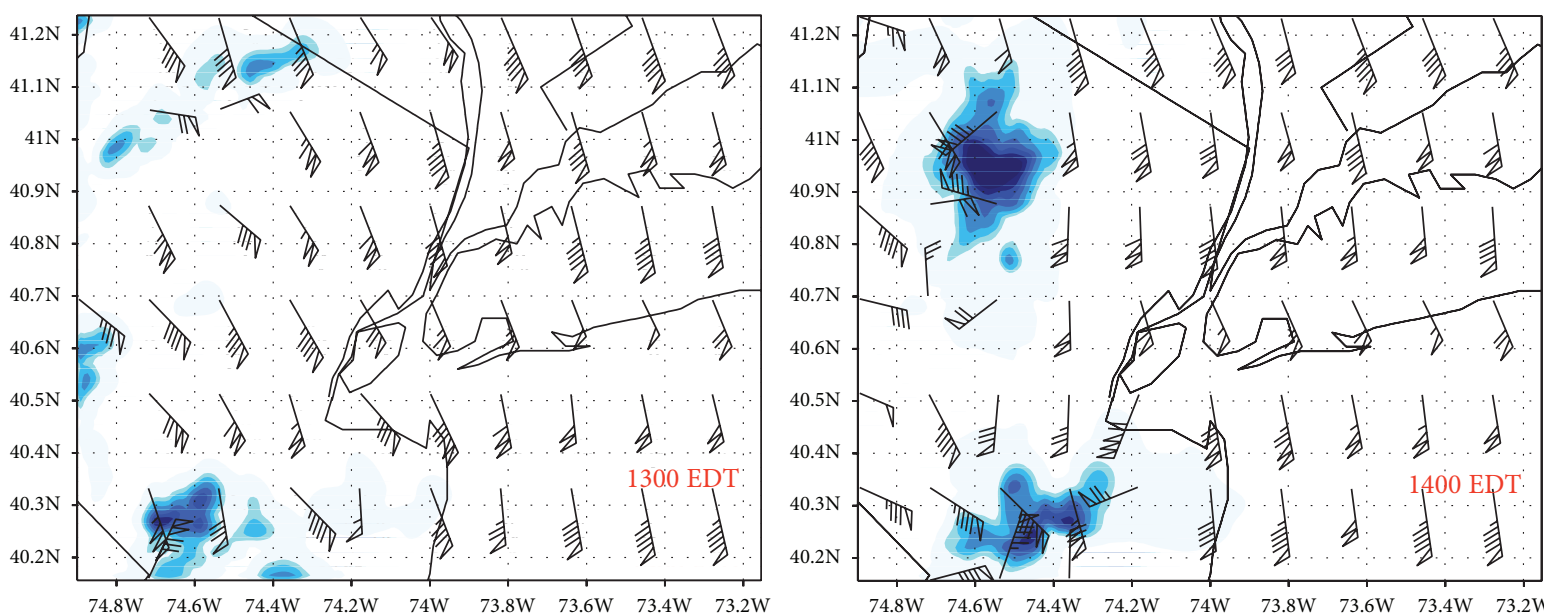

(b)
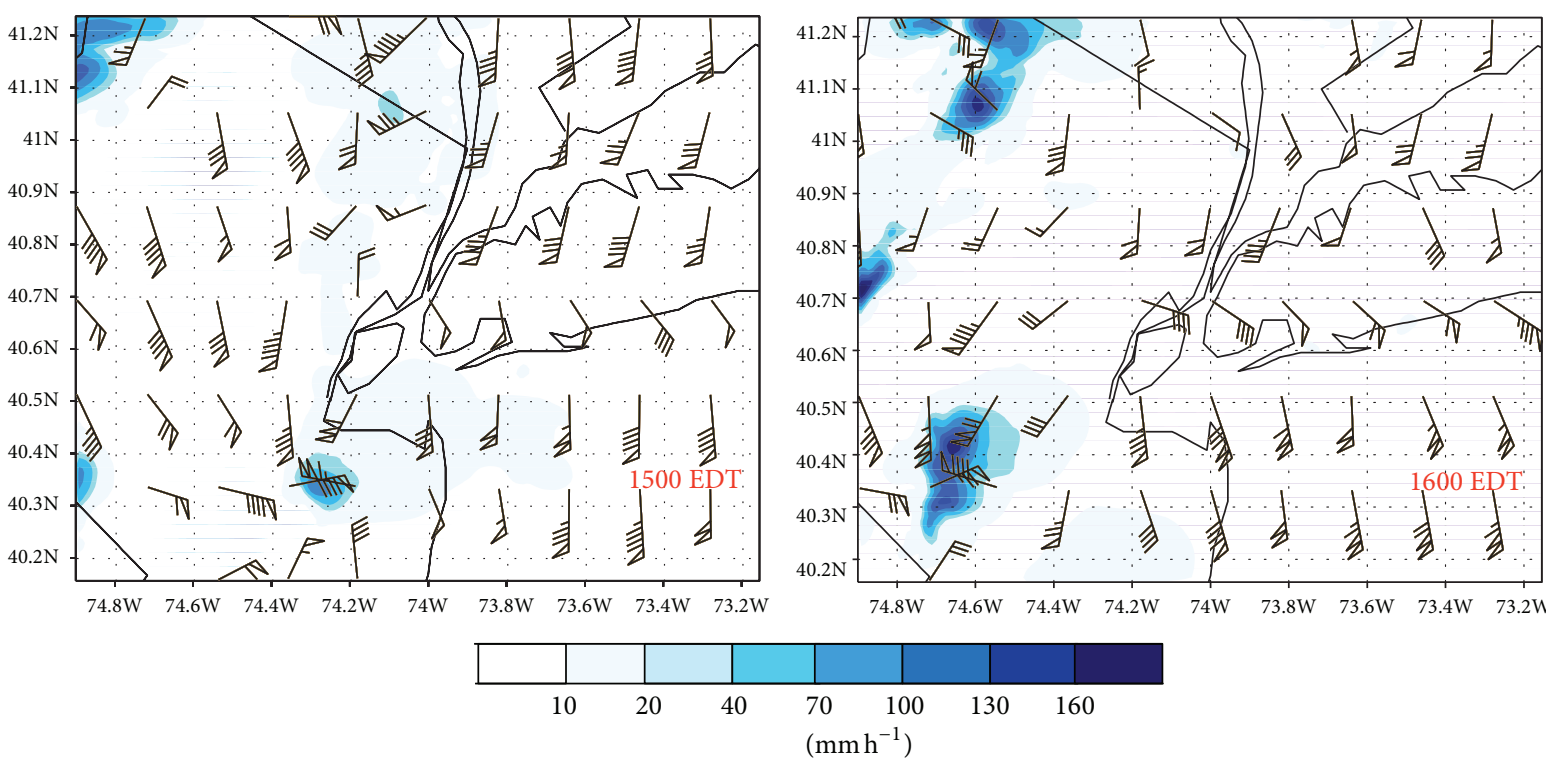

(c)

FIGURE 8: Hourly precipitation rates for Run 1 over topography $\left(1\right.$ wind barb $\left.=1 \mathrm{~ms}^{-1}\right)$. 
11 July, 2007, total accumulated precipitation
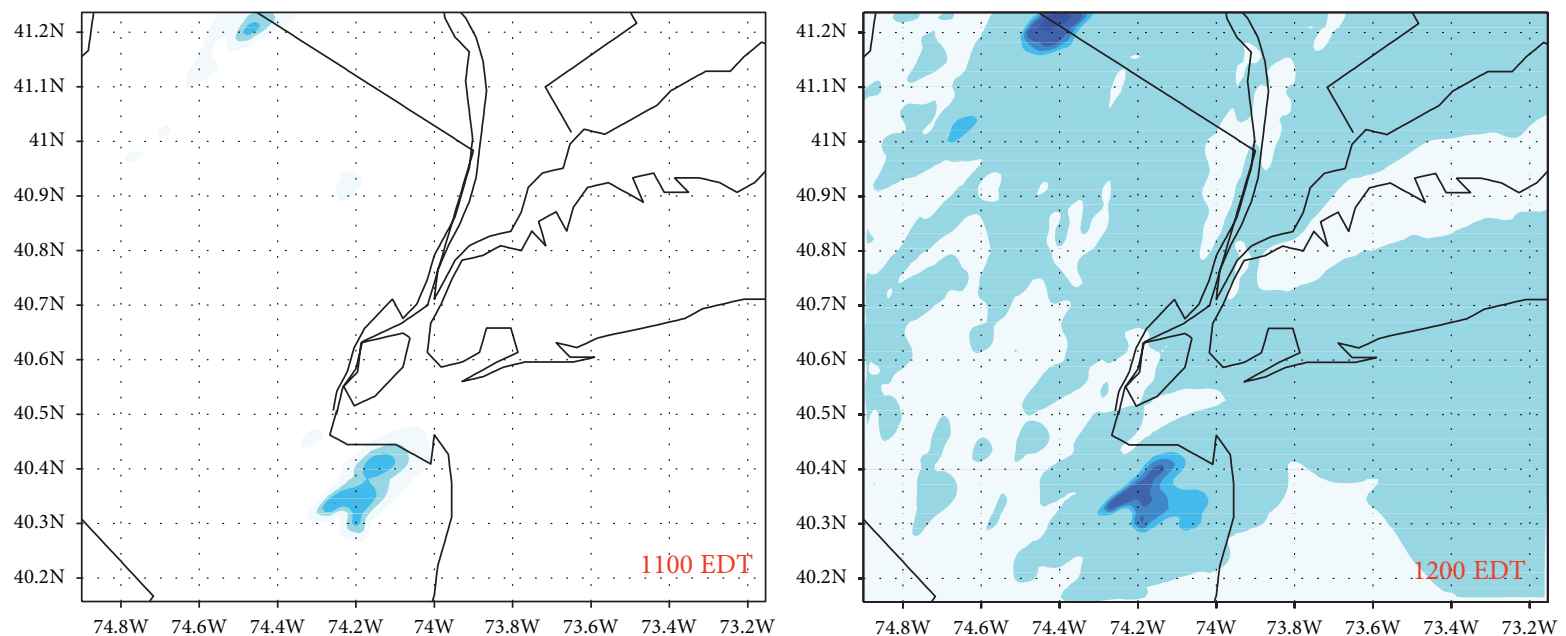

(a)
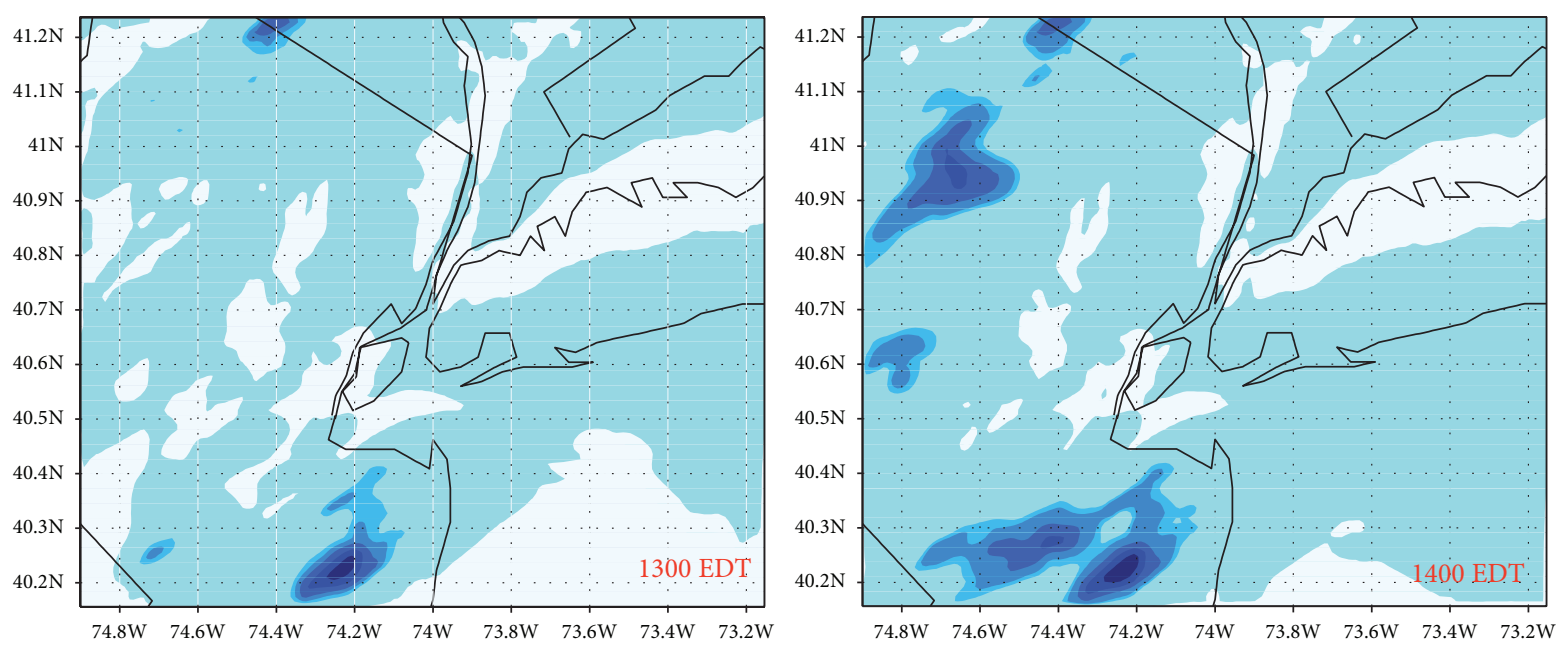

(b)
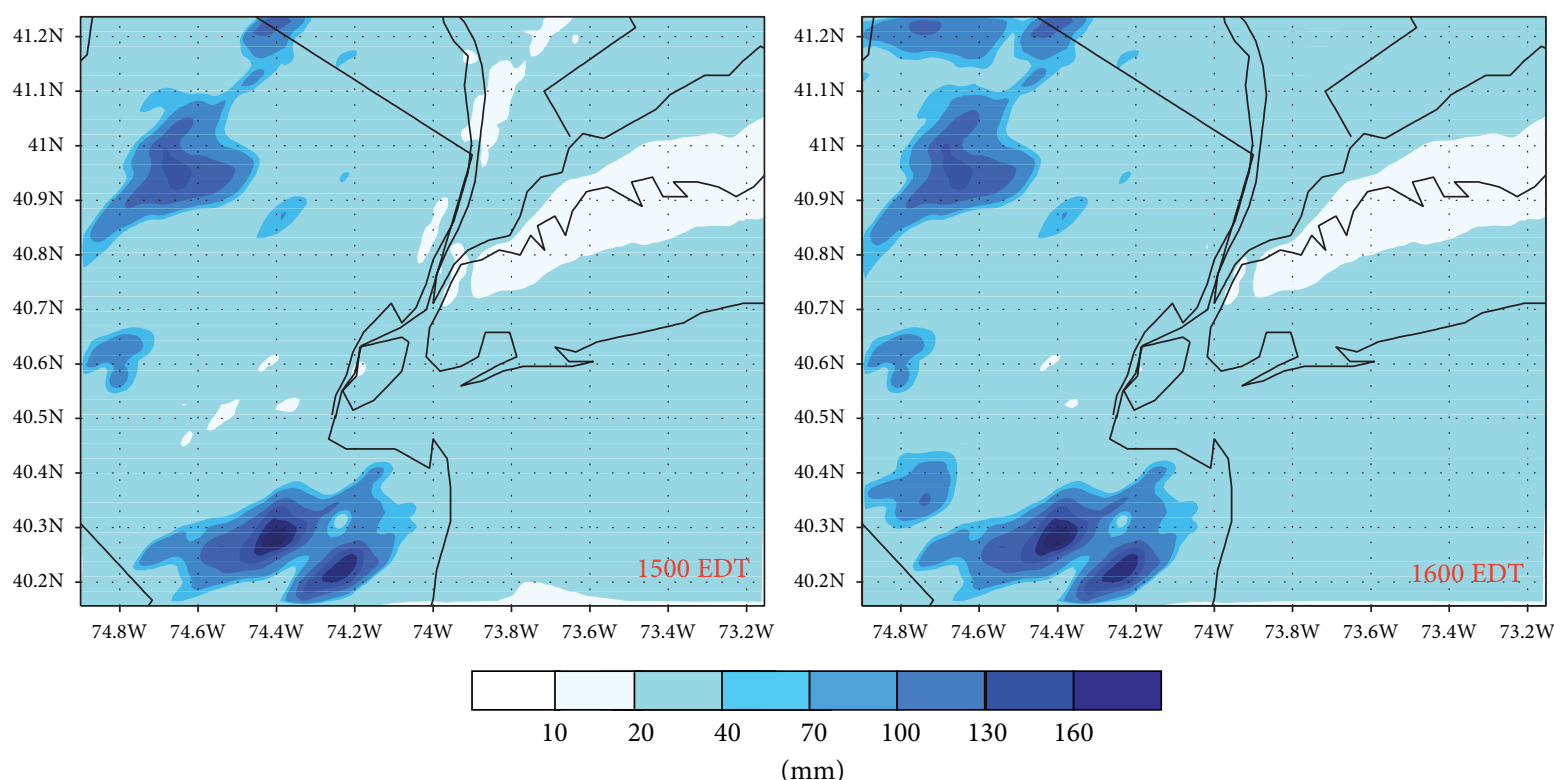

(c)

FIGURE 9: Hourly total accumulated precipitation for Run 1 over topography. 
11 July, 2007, run 1 minus run 2 total accumulated precipitation difference
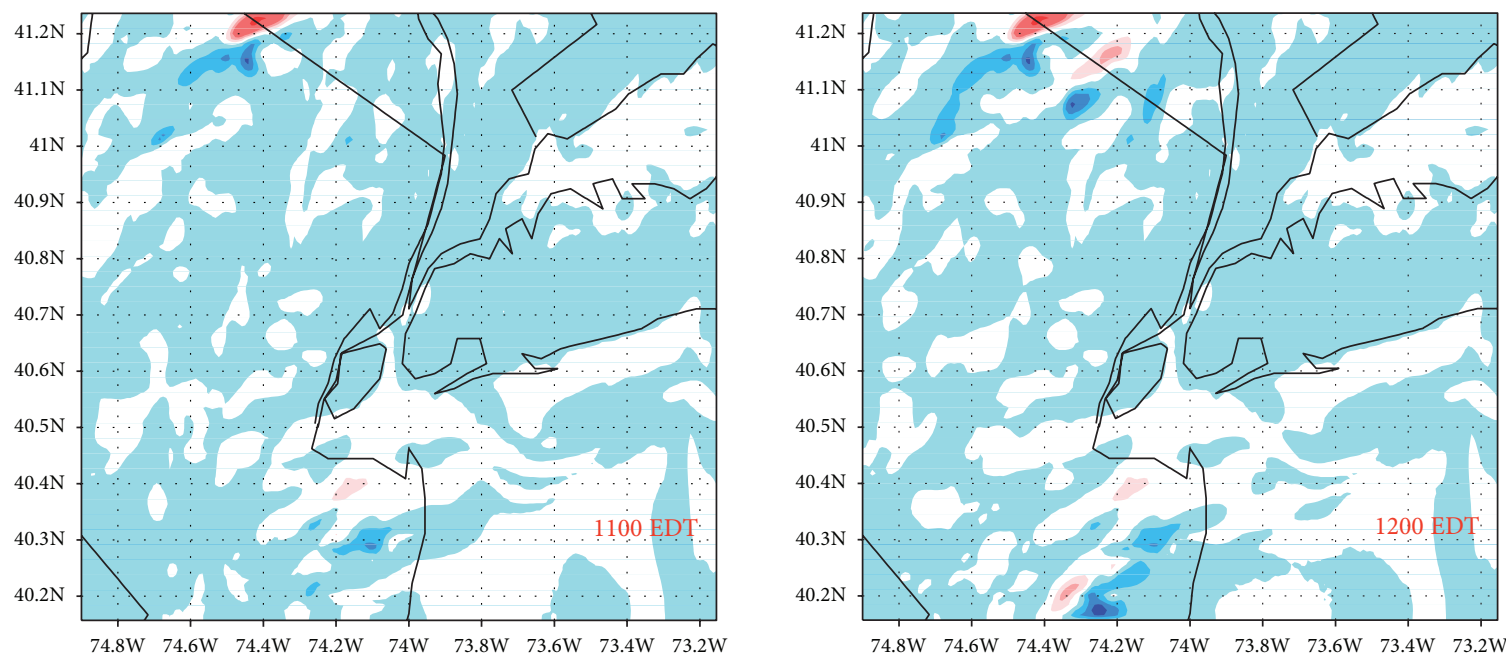

(a)
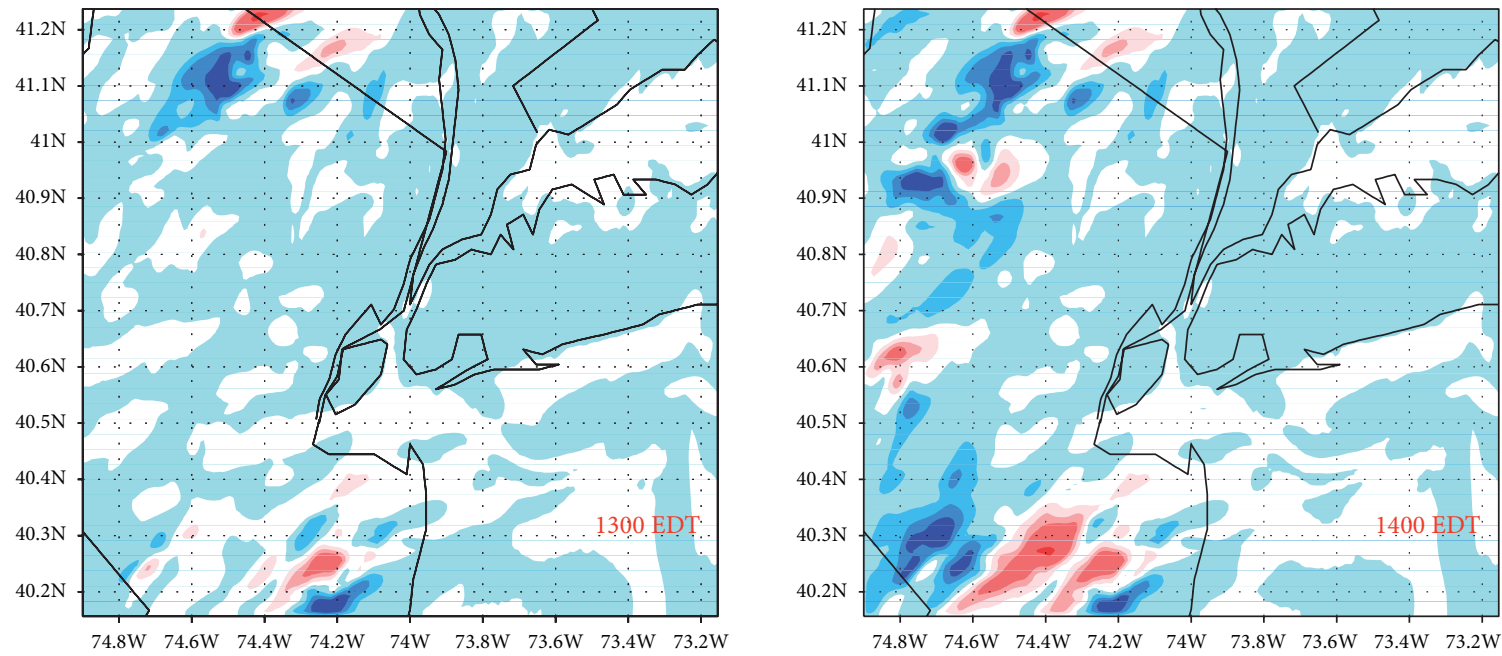

(b)
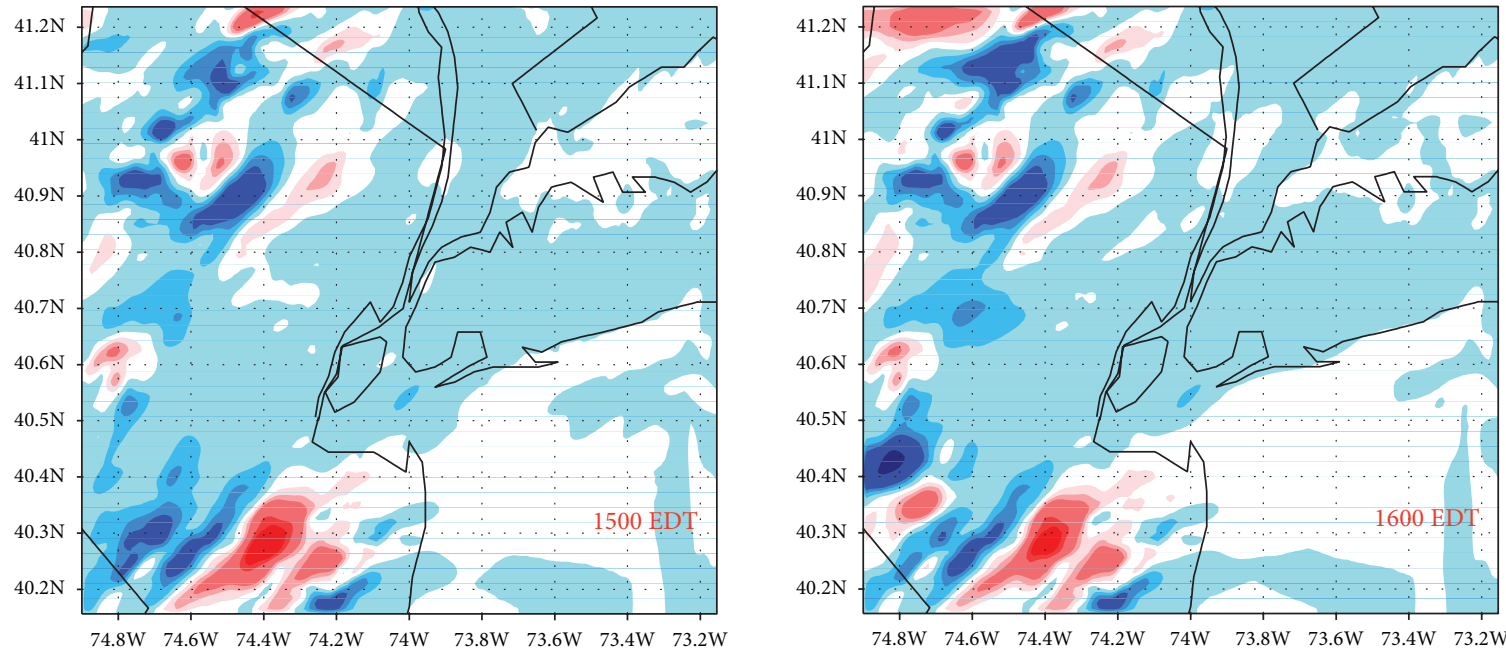

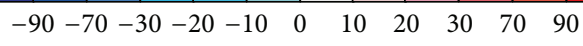

$(\mathrm{mm})$

(c)

FIGURE 10: Hourly total accumulated precipitation difference between Run 1 and Run 2 over topography. 
TABLE 1: Experimental matrix.

\begin{tabular}{lccr}
\hline Run & Land & Aerosol & Duration \\
\hline NI-C & City & Constant PSD & 744 hours (July 2007) \\
I-C & City & 11 PSD updates & 744 hours (July 2007) \\
NI-NC & No City & Constant PSD & 744 hours (July 2007) \\
I-NC & No City & 11 PSD updates & 744 hours (July 2007) \\
Run 1 & City & HVFM (July 11, 2007) & 24 hours (July 11, 2007) \\
Run 2 & City & HVCM (July 18, 2007) & 24 hours (July 11, 2007) \\
Run 3 & No City & HVFM (July 11, 2007) & 24 hours (July 11, 2007) \\
Run 4 & No City & HVCM (July 18, 2007) & 24 hours (July 11, 2007) \\
\hline
\end{tabular}

TABLE 2: Total monthly precipitation (in $\mathrm{mm}$ ) for July 2007 runs. Blue depicts positive biases, red depicts negative biases, and black depicts total accumulated precipitation differences of $1 \mathrm{~mm}$ between NWS values and simulated results.

\begin{tabular}{|c|c|c|c|c|c|}
\hline & $\begin{array}{l}\text { July } 2007 \\
\text { NWS }\end{array}$ & $\begin{array}{c}\text { July } 2007 \\
\text { No City/No PSD } \\
\text { updates (NI-NC) }\end{array}$ & $\begin{array}{c}\text { July } 2007 \\
\text { City/PSD updates (I) }\end{array}$ & $\begin{array}{c}\text { July } 2007 \\
\text { City/No PSD updates } \\
\text { (NI) }\end{array}$ & $\begin{array}{c}\text { July } 2007 \\
\text { No City/PSD updates } \\
\text { (I-NC) }\end{array}$ \\
\hline Mineola & 218 & 138 & 120 & 147 & 89 \\
\hline Oceanside & 110 & 110 & 115 & 125 & 113 \\
\hline Wantaugh & 84 & 111 & 85 & 115 & 106 \\
\hline Bound Brook & 120 & 117 & 120 & 180 & 201 \\
\hline Canistear RSVR & 112 & 190 & 153 & 160 & 157 \\
\hline Canoe Brook & 223 & 193 & 150 & 193 & 167 \\
\hline Essex Fells & 194 & 137 & 156 & 177 & 116 \\
\hline Harrison & 163 & 164 & 164 & 155 & 110 \\
\hline New Brunswick & 141 & 83 & 137 & 149 & 105 \\
\hline New Milford & 183 & 88 & 125 & 120 & 79 \\
\hline Plainfield & 139 & 110 & 150 & 148 & 175 \\
\hline JFK & 134 & 109 & 134 & 131 & 111 \\
\hline Central Park & 175 & 153 & 177 & 150 & 104 \\
\hline EWR & 170 & 155 & 171 & 179 & 137 \\
\hline LGA & 180 & 168 & 180 & 168 & 89 \\
\hline Secaucus & 81 & 166 & 83 & 98 & 97 \\
\hline
\end{tabular}

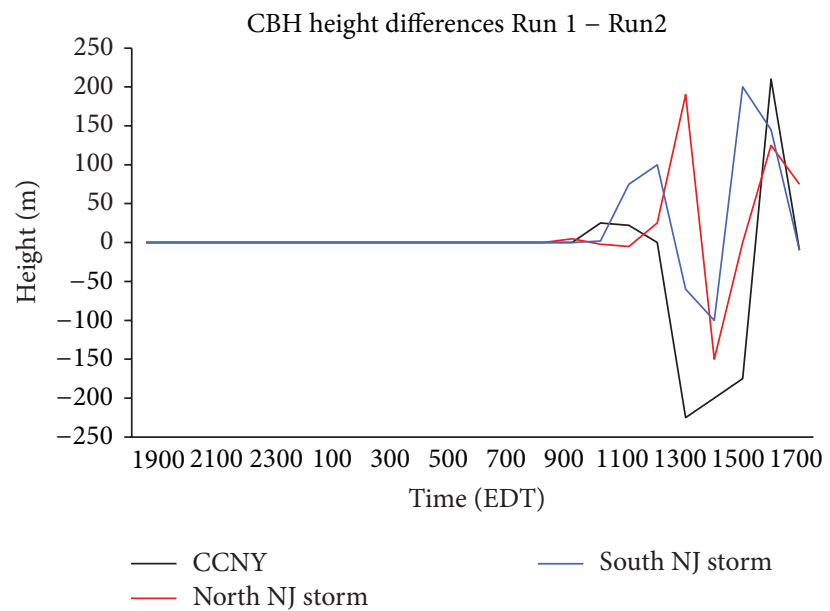

FIGURE 11: CBH differences for three sites for Run 1 minus Run 2 (HVFM-HVCM, City Case) within the region of interest. totals and spatial orientation of the storms. Runs 2-4 are used to determine deviation from Run 1, thus determining ingestion/assimilation effects of different PSDs/LCLU on the precipitation event.

3.2.1. Runs 1 and 2 City Cases. The weak UHI shown in the temperature plots of Figure 7 will not initiate storms over NYC, but warmer NJ does experience precipitation in higherelevation locations. The falling rain cools surface temperature in these areas. Precipitation rate by hour for Run 1 in Figure 8 shows that southerly synoptic flows turn into a southeasterly sea breeze over coastal NJ. The $50 \mathrm{~m}$ hill in that area triggers moderate precipitation, with an area of precipitation at a similar rate on the western boundary in the $300 \mathrm{~m}$ height area. By 1100 EDT, southerly flow from the sea breeze shifts to an organized southeasterly flow over eastern NJ, and isolated regions of light convective precipitation formed over the 
July 2007 total accumulated precipitation (City and No City)

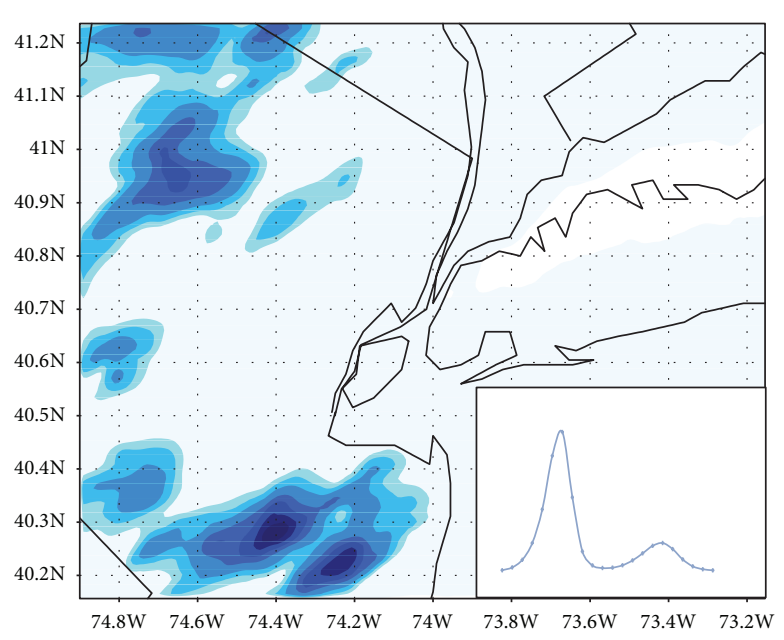

(a)

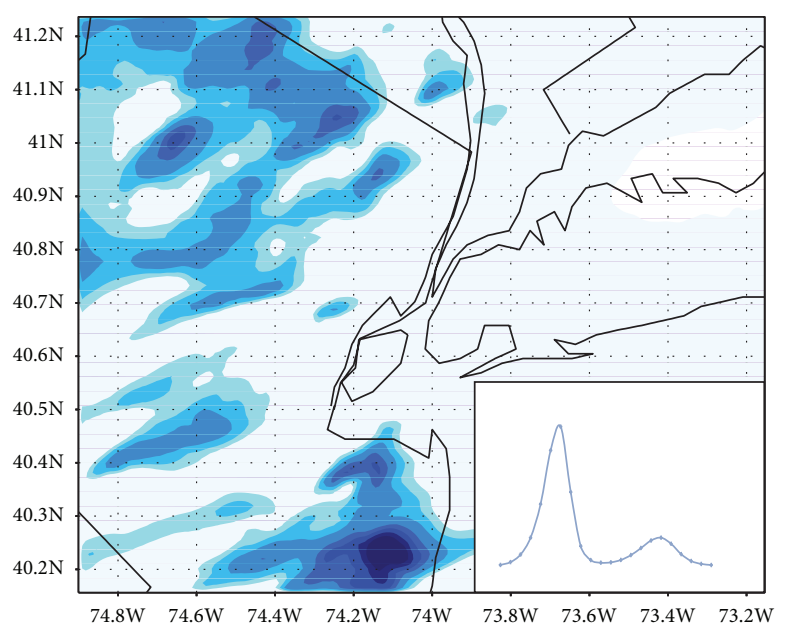

(c)

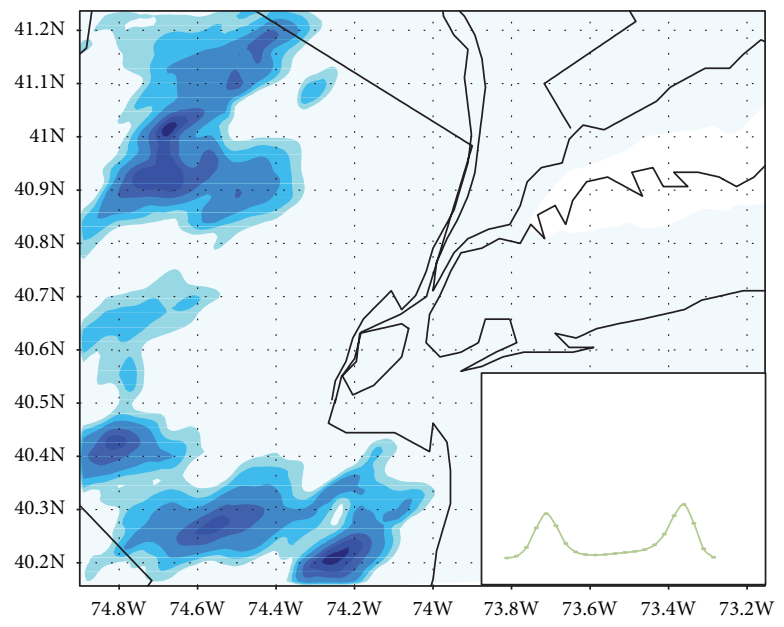

(b)

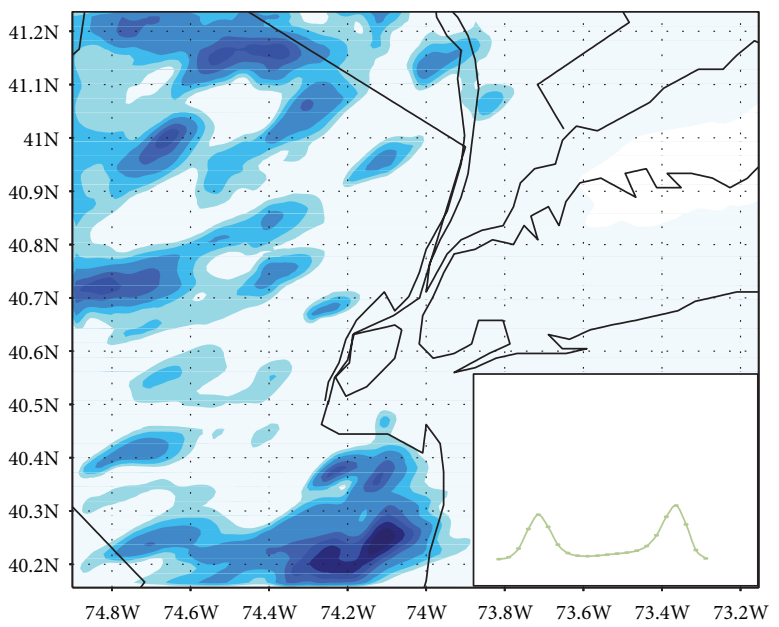

(d)

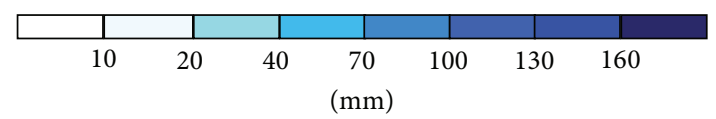

Figure 12: PSD and LCLU variation. (a) HVFM PSD, City (Run 1). (b) HVCM PSD, City (Run 2). (c) HVFM PSD, No City (Run 3). (d) HVFM PSD, No City (Run 4).

region, with moderate precipitation occurring in NJ. By 1200 EDT, the southeasterly flow has extended westward over NJ and precipitation areas have slightly strengthened. By 1600 EDT, flow diverges around NYC and half a cyclonic-vortex forms downwind over NJ. The most intense precipitation occurs west of $74 \mathrm{~W}$, in northern and southern NJ. The centers of the two major storm cells do not move far from their origins. Results for total accumulated precipitation (Figure 9) show that maximum precipitation occurs downwind of NYC, consistent with findings by Huff and Changnon [7] and Bornstein and Lin [41] which showed that the presence of a city can act to shift maximum precipitation totals. Since NYC is a coastal urban area, the sea breeze may also factor into pushing the maximum precipitation downwind.
Figure 10 shows precipitation differences for Run 1 minus Run 2 (course mode run). Precipitation enhancement (denoted by negative values) due to the presence of bigger and more numerous GCCN particles over most of the region, including the northwestern storm $(41 \mathrm{~N} / 74.6 \mathrm{~W})$, occurs with the introduction of HVCM PSD. It should be noted that the exact nature of these particles is unknown. Due to the proximity of the East River, Hudson River, and Atlantic Ocean to NYC, GCCN particles may be of marine origin rather than anthropogenic origin. There is some suppression (denoted by positive values) at the center of the southwestern storm $(40.25 \mathrm{~N} / 74.15 \mathrm{~W})$. The outer perimeter of both storms experience suppression, attributed to the fact that GCCN particles rain out faster and require more time for newly 
July 11, 2007, City/No City precipitation differences

Run 1 - Run 3

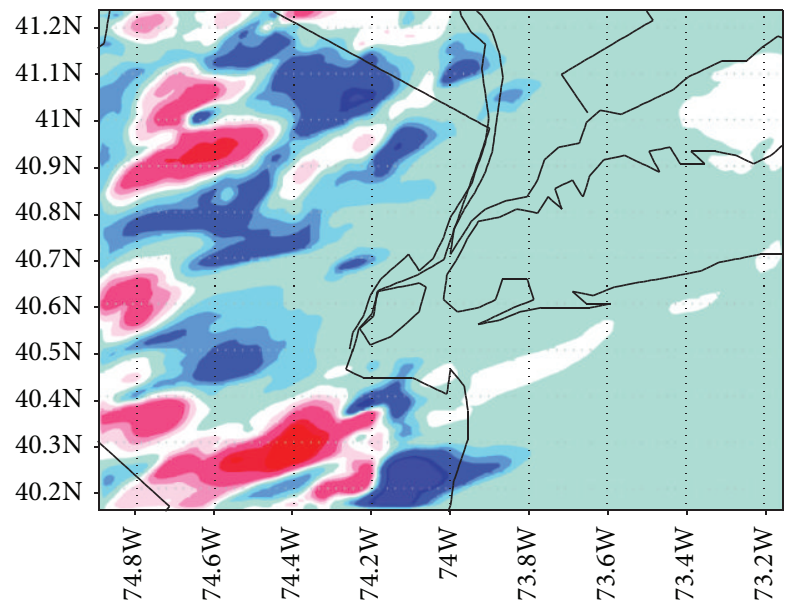

(a)
Run 1 - Run 4

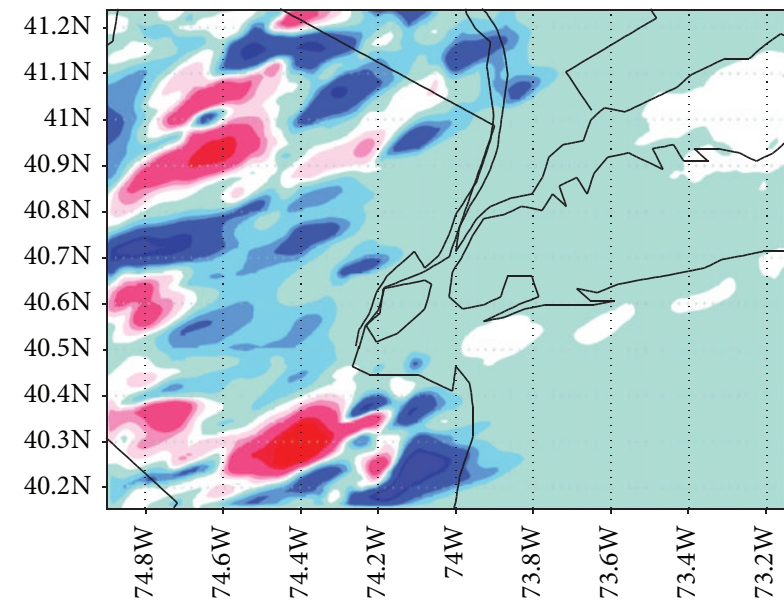

(b)

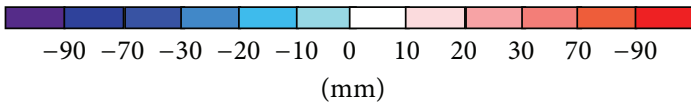

Figure 13: (a) Precipitation differences for Run 1 minus Run 3. (b) Precipitation differences for Run 1 minus Run 4.

Total accumulated precipitation histograms

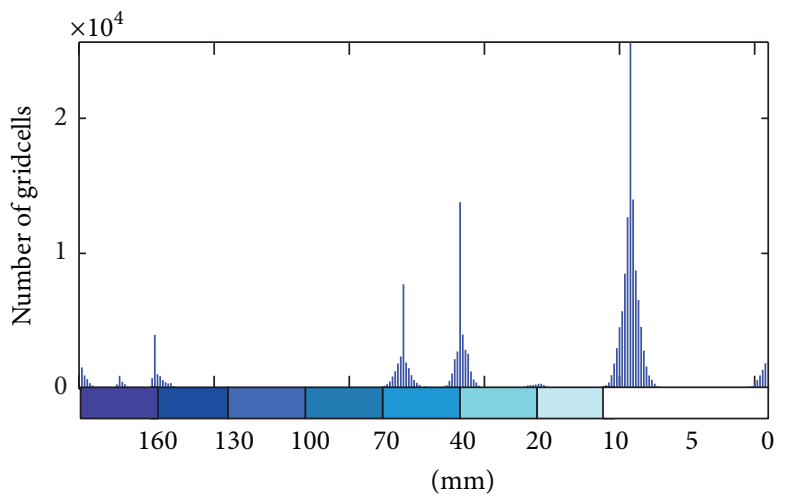

(a)

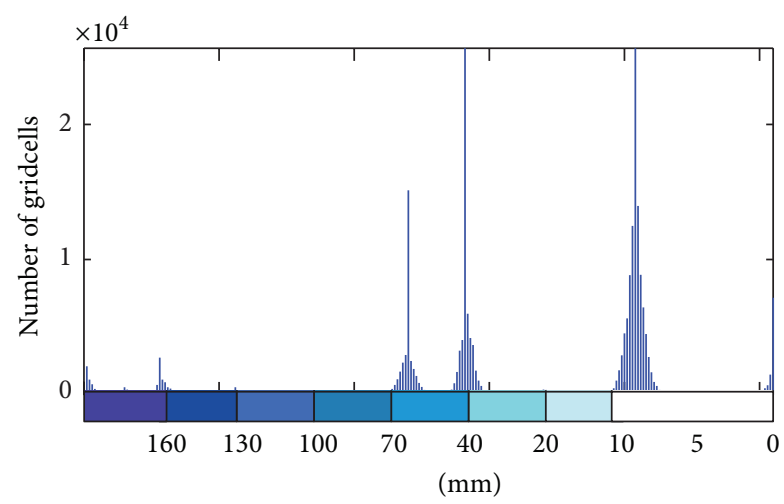

(c)

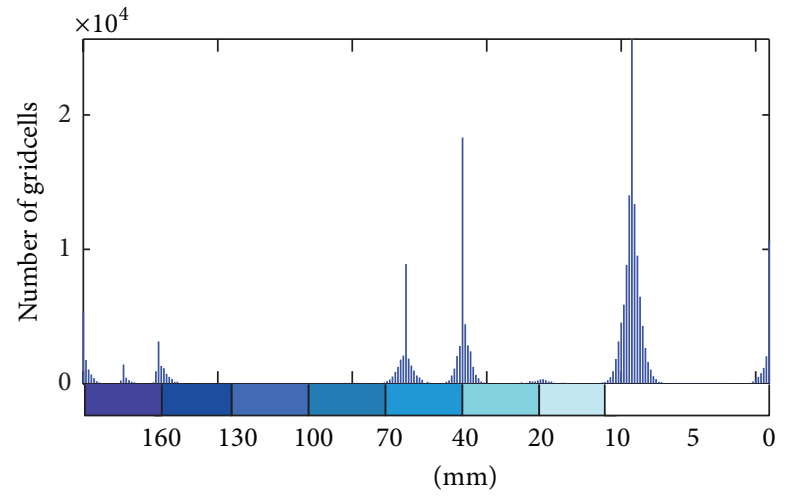

(b)

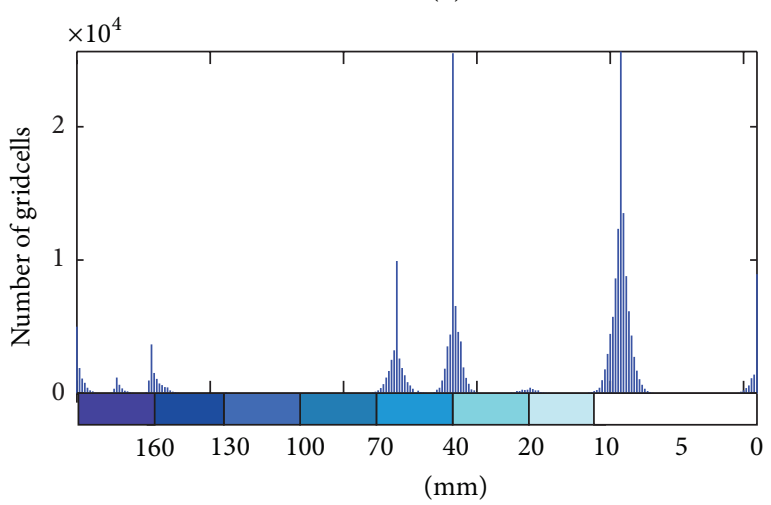

(d)

Figure 14: Number of grid cells per accumulated precipitation total for (a) Run 1, (b) Run 2, (c) Run 3, and (d) Run 4. 
2007, vertical wind speed (City and No City)
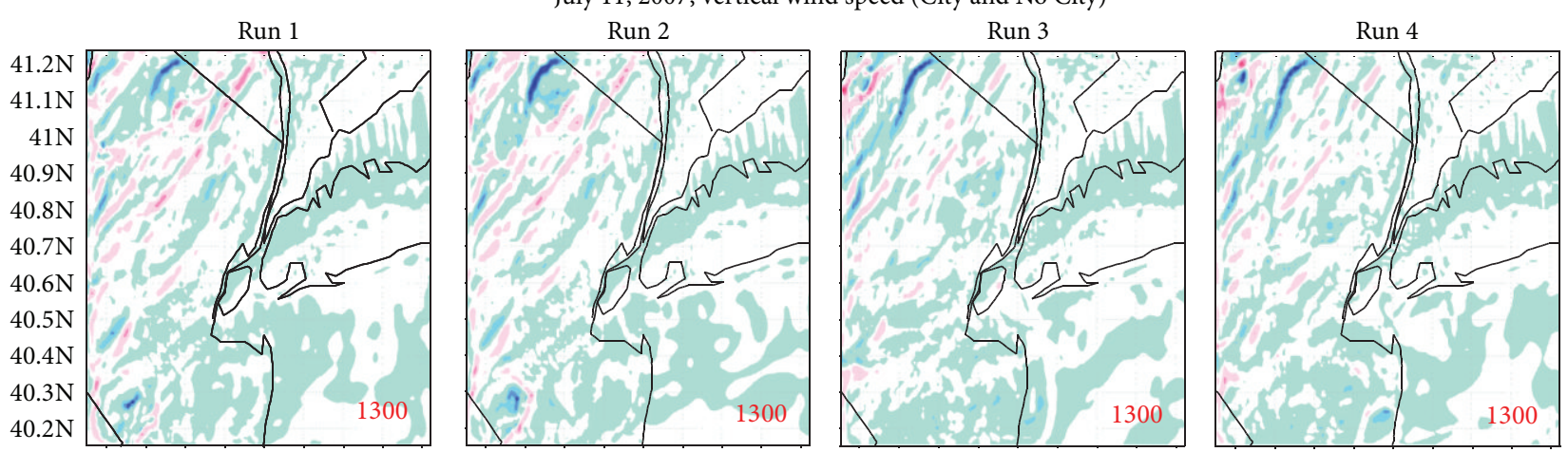

(a)
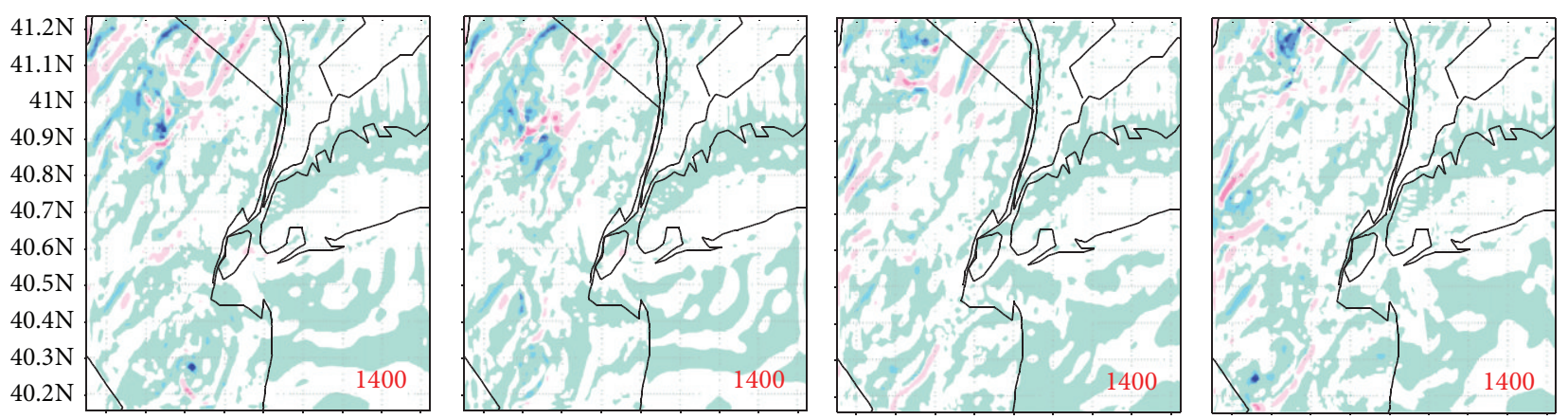

(b)
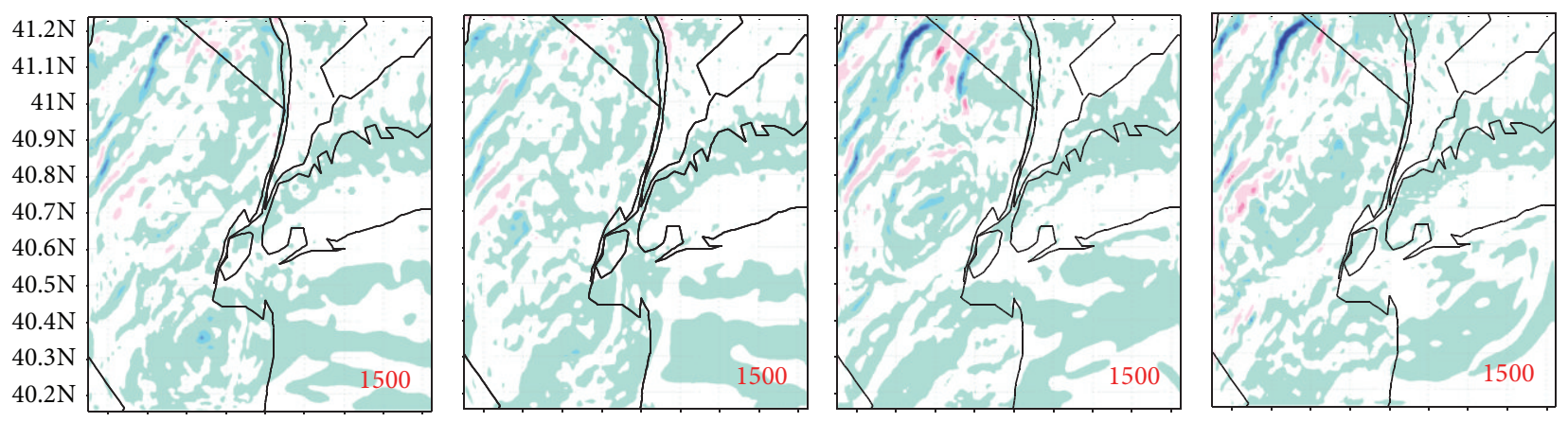

(c)
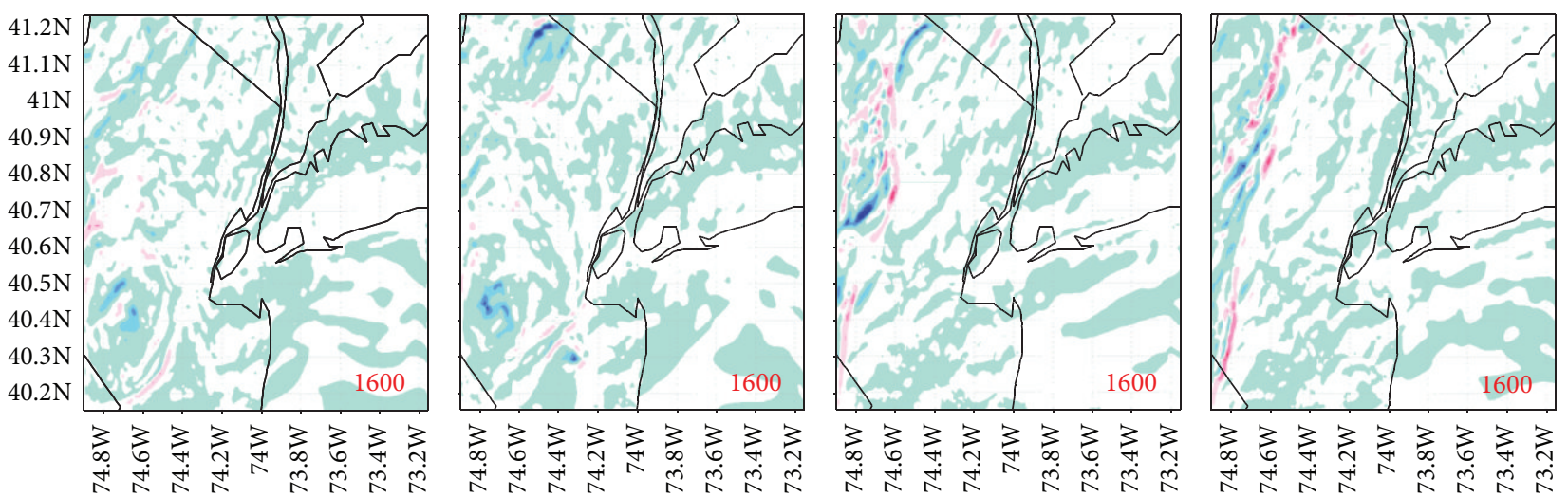

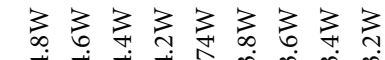

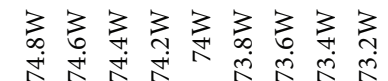

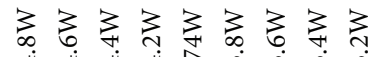

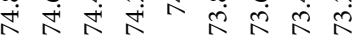

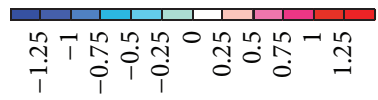

$\left(\mathrm{m} \mathrm{s}^{-1}\right)$

(d) 


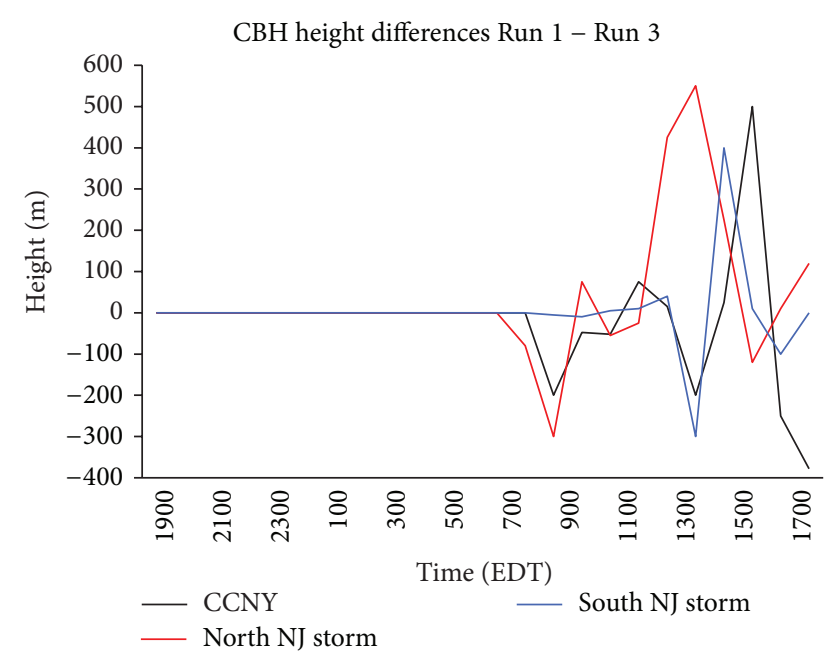

Figure 16: CBH differences between Run 1 and Run 3 for three different sites.

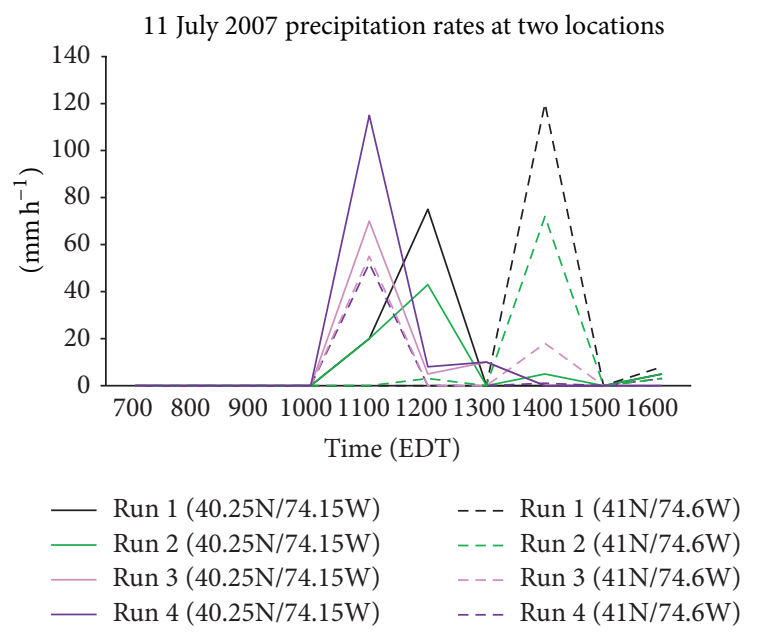

FIgURE 17: Precipitation rates for all July 11, simulations for two major storms over NJ, for City and No City cases.

activated particles to grow after the initial rain out while $\mathrm{CCN}$ delay rain due to their smaller size. When the smaller particles eventually reach raindrop size, they can increase the storm intensity [9]. Higher regions experience enhancement because they are closer to atmospheric conditions favorable for precipitation to occur. The cooler air at heights above $300 \mathrm{~m}$ accelerates droplet growth.

Analysis of cloud base height (CBH) differences for CCNY, the northern NJ storm, and the southern NJ storm (Figure 11) shows that $\mathrm{CBH}$ does not differ for the first 12 hours of simulation. In each of the three cases, there is initial positive difference, which means that Run 1 exhibited higher $\mathrm{CBH}$ than did Run 2. During the most intense rainfall, 1100$1300 \mathrm{EDT}$, there is a negative difference for each of the three sites, indicating that Run 2 exhibited higher CBH than Run 1. These results show that increased CCN delays the occurrence of the intense precipitation, while GCCN causes the cloud to rain out early, allowing for newly activated CCN to rise higher in Run 2 before they grow enough to overcome cloud updrafts.

3.2.2. Runs 3 and 4 No City Cases. Model results show that Runs 3 (HVFM PSD, No City) and 4 (HVCM PSD, No City) produce more precipitation between the $40.4 \mathrm{~N}$ and $40.9 \mathrm{~N}$ latitudes and also extend further east than Runs 1 and 2 (Figure 12). Although removal of the city does not increase totals by more than a few $\mathrm{mm}$ over Manhattan and along Long Island, the further eastward extension of major precipitation over the region is indication of the LCLU impacting precipitation. With the presence of the city (Runs 1 and 2), heavy precipitation is pushed westward and it is less scattered and more intense. The city is forcing this precipitation further downwind.

Replacing high volume of CCN (Run 3) with high volume of GCCN (Run 4) results in precipitation enhancement due to the presence of a greater volume of GCCN. Precipitation differences for Run 1 minus Run 3 (Figure 13) show suppression due to the presence of the city (indicated by the italic font) over most of the region except at locations of maximum precipitation (near storms at $40.25 \mathrm{~N} / 74.15 \mathrm{~W}$ and $41 \mathrm{~N} / 74.6 \mathrm{~W})$. A domain-wide statistical analysis was performed on total accumulated precipitation (Figure 14) for each of the four daily simulations. Plots show that No City Runs 3 and 4 (Figures 14(c) and 14(d)) have more grid cells with near max totals than City Runs 1 and 2 (Figures 14(a) and 14(b)). Run 4 exhibits the largest number of grid cells with precipitation totals over $100 \mathrm{~mm}$, followed by Runs 3, 2, and 1 . Run 3 has 5\% less grid cells higher than $130 \mathrm{~mm}$ than Run 4, and Runs 2 and 1 have $25 \%$ less grid cells higher than $130 \mathrm{~mm}$ than Run 4 . Runs 3 and 4 also exhibit 52\% more grid cells above $15 \mathrm{~mm}$ than Runs 1 and 2 .

Vertical wind plots in Figure 15 show evidence of stronger convection west of NYC for City runs than No City runs from 1300 to 1400 EDT. From 1500 to 1600 EDT, strengthened convection over NJ for Runs 3 and 4 is shown. After rain is purged from the cloud Runs 1 and 2 take longer to produce more rain, attributed to modified land-atmosphere interactions for City and No City LCLU. Analysis of CBH differences calculated for Run 1 minus Run 3 for CCNY, the northern NJ storm, and the southern NJ storm (Figure 16) show that $\mathrm{CBH}$ does not differ for the first 12 hours of simulation. The impact of LCLU variation becomes evident at $0800 \mathrm{EDT}$. In each of the three cases, there is an initial positive difference, (Run 1 exhibited higher CBH's than did Run 3). During the most intense rainfall (1100-1300 EDT) there is a negative difference for each of the three sites, indicating that Run 1 exhibited higher CBH than Run 3. These results suggest that the presence of the city adds convection, which elevates $\mathrm{CBH}$ higher between these times. Precipitation rates (Figure 17) increase faster in Runs 3 and 4 for both storms. In the southern storm, Runs 3 and 4 experience the highest precipitation rates $(80-110 \mathrm{~mm} / \mathrm{h})$, while values for Runs 1 and 2 experience a broader range of precipitation rates (from 1 to $130 \mathrm{~mm} / \mathrm{h}$ ). 


\section{Conclusions}

The aim of this paper was to investigate the role of aerosol particle size distribution (PSD) and land cover land use (LCLU) on storms over and near NYC. PSDs/LCLU obtained from AERONET/NLCD were ingested/assimilated into RAMS and precipitation results for all cases were compared. Results show that precipitation forecasting is improved when observed PSDs are and present LCLU is ingested/assimilated. For 12 of 16 different sites, runs with observed PSD/present LCLU show reduced error over runs that did not have either observed PSD updates or current LCLU.

The deviation from observations is much higher in No City cases than in City cases. Accuracy increases with PSD updates. Analysis of $\mathrm{CBH}$ differences suggests that added convection induced by the presence of the city elevates CBH higher. These results support the notion that cities can impact precipitation by potential aerosol concentration increases and size modification associated with the city. Convection induced by the city landscape draws natural aerosols higher into the atmosphere as well. Results show that PSD with a high volume of fine mode particles (HVFM) can suppress precipitation, while a PSD with a high volume of coarse mode particles (HVCM) can enhance accumulated precipitation totals. Spatial precipitation patterns also change.

These PSD effects are attributed to hastened/reduced rates of autoconversion due to the presence of higher volumes of GCCN/CCN (reduced GCCN number concentration can result in increased GCCN volume when the modal radius is large as is the case in July 18,2007), which enhances/impedes droplet coalescence rates, in agreement with work by Rosenfeld [15], Rosenfeld et al. [24], and Comarazamy et al. [25]. Results may be further improved with assimilation of higher resolution and or more frequent boundary data.

\section{Conflict of Interests}

The authors declare that there is no conflict of interests regarding the publication of this paper.

\section{Acknowledgments}

The authors would like to thank Robert D. Bornstein for his energy and interest in this paper. This paper was made possible by the National Oceanic and Atmospheric Administration, Office of Education Educational Partnership Program award NA11SEC4810004. Its contents are solely the responsibility of the award recipient and do not necessarily represent the official views of the US Department of Commerce, National Oceanic and Atmospheric Administration.

\section{References}

[1] R. D. Bornstein, "Observations of the urban heat island effect in New York City," Journal of Applied Meteorology, vol. 7, no. 4, pp. 575-582, 1968.

[2] H. E. Landsberg, The Urban Climate, Academic Press, New York, NY, USA, 1981.
[3] K. Noto, "Dependence of heat island phenomena on stable stratification and heat quantity in a calm environment," Atmospheric Environment, vol. 30, no. 3, pp. 475-485, 1996.

[4] E. Jauregui, "Heat island development in Mexico City," Atmospheric Environment, vol. 31, no. 22, pp. 3821-3831, 1997.

[5] P. Dixon and T. Mote, "Patterns and causes of Atlanta's urban heat island-initiated precipitation," Journal of Applied Meteorology, vol. 42, no. 9, pp. 1273-1284, 2003.

[6] J. M. Shepherd, "A review of current investigations of urbaninduced rainfall and recommendations for the future," Earth Interactions, vol. 9, no. 1, pp. 1-27, 2005.

[7] F. A. Huff and S. A. Changnon, "Precipitation modification by major urban areas," Bulletin of the American Meteorological Society, vol. 54, no. 12, pp. 1220-11232, 1973.

[8] R. Bornstein and M. LeRoy, "Urban barrier effects on convective and frontal thunderstorms," in Proceedings of the 4th Conference on Mesoscale Processes, pp. 120-121, American Meteorological Society, Boulder, Colo, USA, 1990.

[9] G. Carrio, W. R. Cotton, and W. Cheng, "Urban growth and aerosol effects on convectionover Houston," Atmospheric Research, vol. 96, no. 4, pp. 560-574, 2010.

[10] K. C. S. Ray and A. K. Srivastava, "Is there any change in extreme events like heavy rainfall?" Current Science, vol. 79, no. 2, pp. 155-158, 2000.

[11] J. M. Shepherd, "Evidence of urban-induced precipitation variability in arid climate regimes," Journal of Arid Environments, vol. 67, no. 4, pp. 607-628, 2006.

[12] N. Selover, "Precipitation patterns around an urban desert environment topographic or urban influences," in Proceedings of the Association of American Geographers Convention, pp. 2529, Fort Worth, Tex, USA, May 1997.

[13] J. M. Shepherd, H. Pierce, and A. J. Negri, "Rainfall modification by major urban areas: observations from spaceborne rain radar on the TRMM satellite," Journal of Applied Meteorology, vol. 41, no. 7, pp. 689-701, 2002.

[14] D. Niyogi, P. Pyle, M. Lei et al., "Urban modification of thunderstorms: an observational storm climatology and model case study for the Indianapolis urban region," Journal of Applied Meteorology and Climatology, vol. 50, no. 5, pp. 1129-1144, 2011.

[15] D. Rosenfeld, "TRMM observed first direct evidence of smoke from forest fires inhibiting rainfall," Geophysical Research Letters, vol. 26, no. 20, pp. 3105-3108, 1999.

[16] D. Rosenfeld, "Suppression of rain and snow by urban and industrial air pollution," Science, vol. 287, no. 5459, pp. 17931796, 2000.

[17] K. M. Lau and K. M. Kim, "Observational relationship between aerosol and Asian monsoon circulation rainfall," Geophysical Research Letters, vol. 33, no. 21, Article ID L21810, 2006.

[18] W. W. Grabowski, "A parameterization of cloud microphysics for long-term cloud-resolving modeling of tropical convection," Atmospheric Research, vol. 52, no. 1-2, pp. 17-41, 1999.

[19] V. Ramanathan, P. J. Crutzen, J. Lelieveld et al., "Indian ocean experiment: an integrated analysis of the climate forcing and effects of the great Indo-Asian haze," Journal of Geophysical Research D, vol. 106, no. 22, pp. 28371-28399, 2001.

[20] R. D. Borys, D. H. Lowenthal, and D. L. Mitchell, “The relationships among cloud microphysics, chemistry, and precipitation rate in cold mountain clouds," Atmospheric Environment, vol. 34, no. 16, pp. 2593-2602, 2000.

[21] A. Givati and D. Rosenfeld, "Quantifying precipitation suppression due to air pollution," Journal of Applied Meteorology, vol. 43, no. 7, pp. 1038-1056, 2004. 
[22] I. L. Jirak and W. R. Cotton, "Effect of air pollution on precipitation along the front range of the Rocky Mountains," Journal of Applied Meteorology and Climatology, vol. 45, no. 1, pp. 236-245, 2006.

[23] S. C. van den Heever and W. R. Cotton, "Urban aerosol impacts on downwind convective storms," Journal of Applied Meteorology and Climatology, vol. 46, no. 6, pp. 828-850, 2007.

[24] D. Rosenfeld, U. Lohmann, G. B. Raga et al., "Flood or drought: how do aerosols affect precipitation?" Science, vol. 321, no. 5894, pp. 1309-1313, 2008.

[25] D. E. Comarazamy, J. E. Gonzalez, C. A. Tepley, S. Raizada, and R. V. R. Pandya, "Effects of atmospheric particle concentration on cloud mocrophysics over Arecibo," Journal of Geophysical Research D, vol. 111, no. 9, Article ID D09205, 2006.

[26] O. Dubovik and M. D. King, "A flexible inversion algorithm for retrieval of aerosol optical properties from sun and sky radiance measurements," Journal of Geophysical Research D, vol. 105, no. 16, pp. 20673-20696, 2000.

[27] L. A. Otero, G. J. Fochesatto, P. R. Ristori et al., "Simple method to derive aerosol microphysical properties from AERONET multiwavelength direct solar measurements," Advances in Space Research, vol. 34, no. 10, pp. 2232-2235, 2004.

[28] B. N. Holben, T. F. Eck, I. Slutsker et al., "AERONET's version 2.0 quality assurance criteria," in Remote Sensing of the Atmosphere and Clouds, vol. 6408 of Proceedings of SPIE, Goa, India, November 2006.

[29] T. F. Eck, B. N. Holben, J. S. Reid et al., "Fog- and cloud-induced aerosol modification observed by the aerosol robotic network (AERONET)," Journal of Geophysical Research D, vol. 117, no. 7, Article ID D07206, 2012.

[30] J. S. Reid, R. Koppmann, T. F. Eck, and D. P. Eleuterio, "A review of biomass burning emissions-part II: intensive physical properties of biomass burning particles," Atmospheric Chemistry and Physics, vol. 5, no. 3, pp. 799-825, 2005.

[31] J. A. Fry, G. Xian, S. Jin et al., "Completion of the 2006 national land cover database for the conterminous united states," Photogrammetric Engineering and Remote Sensing, vol. 77, no. 9, pp. 858-864, 2011.

[32] R. L. Walko, W. R. Cotton, M. P. Meyers, and J. Y. Harrington, "New RAMS cloud microphysics parameterization-part I: the single-moment scheme," Atmospheric Research, vol. 38, no. 1-4, pp. 29-62, 1995.

[33] M. P. Meyers, R. L. Walko, J. Y. Harrington, and W. R. Cotton, "New RAMS cloud microphysics parameterization-part II: the two-moment scheme," Atmospheric Research, vol. 45, no. 1, pp. 3-39, 1997.

[34] R. L. Walko and C. J. Tremback, "Modifications for the transition from LEAF-2 to LEAF-3," ATMET Technical Note, 2005.

[35] R. E. Dickinson, A. Henderson-Sellers, P. J. Kennedy, and M. F. Wilson, "Biosphere-atmosphere transfer scheme (BATS) for the NCAR community climate model," Technical Note TN275+STR, National Center for Atmospheric Research, Boulder, Colo, USA, 1986.

[36] E. X. Berry and R. L. Reinhardt, "An analysis of cloud drop growth by collection-part I: double distributions," Journal of the Atmospheric Sciences, vol. 31, no. 7, pp. 1814-1824, 1974.

[37] D. Nagel, A. Herber, L. W. Thomason, and U. Leiterer, "Vertical distribution of the spectral aerosol optical depth in the Arctic from 1993 to 1996," Journal of Geophysical Research D, vol. 103, no. 2, pp. 1857-1870, 1998.
[38] P. J. Flatau, G. J. Tripoli, J. Verlinde, and W. R. Cotton, “The CSU-RAMS cloud microphysical module: general theory and code documentation," Atmospheric Science Paper no. 451, Department of Atmospheric Science, Colorado State University, Fort Collins, Colo, USA, 1989.

[39] S. M. Saleeby and W. R. Cotton, "A large-droplet mode and prognostic number concentration of cloud droplets in the Colorado State University regional atmospheric modeling system (RAMS) - part I: module descriptions and supercell test simulations," Journal of Applied Meteorology, vol. 43, no. 1, pp. 182-195, 2004.

[40] U. Stein and P. Alpert, "Factor separation in numerical simulations," Journal of the Atmospheric Sciences, vol. 50, no. 4, pp. 2107-2115, 1993.

[41] R. Bornstein and Q. Lin, "Urban heat islands and summertime convective thunderstorms in Atlanta: three case studies," Atmospheric Environment, vol. 34, no. 3, pp. 507-516, 2000. 

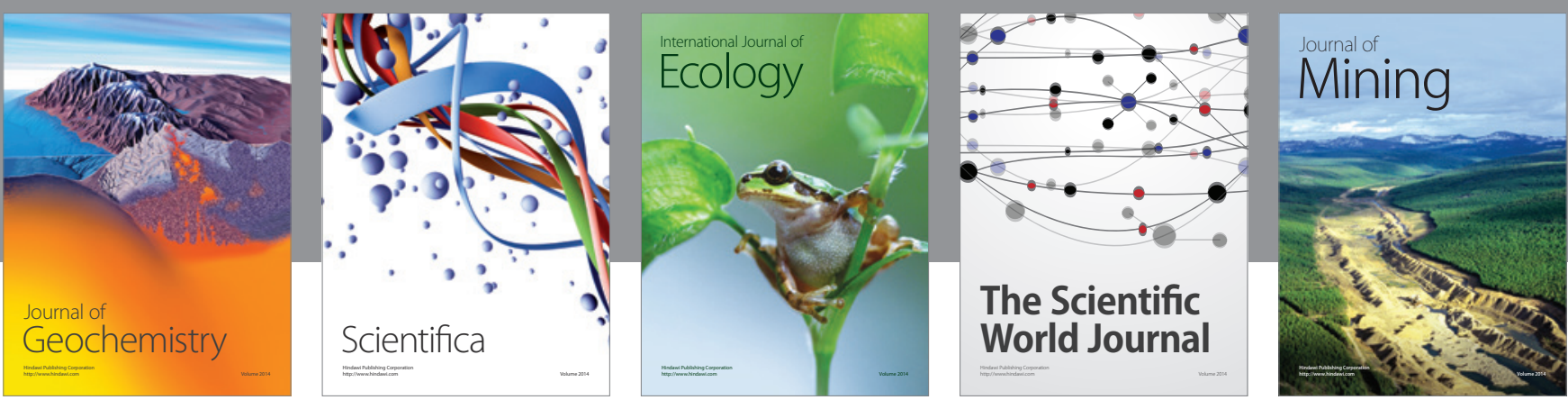

The Scientific World Journal
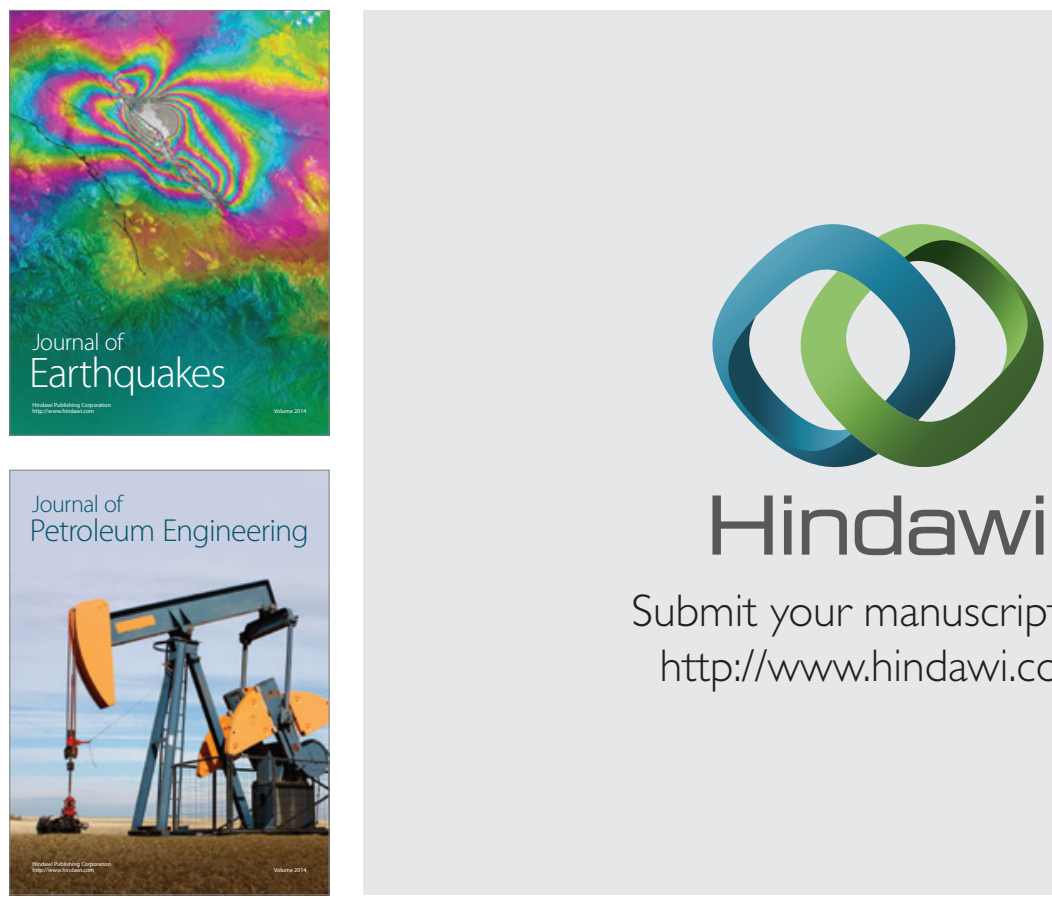

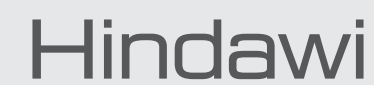

Submit your manuscripts at

http://www.hindawi.com
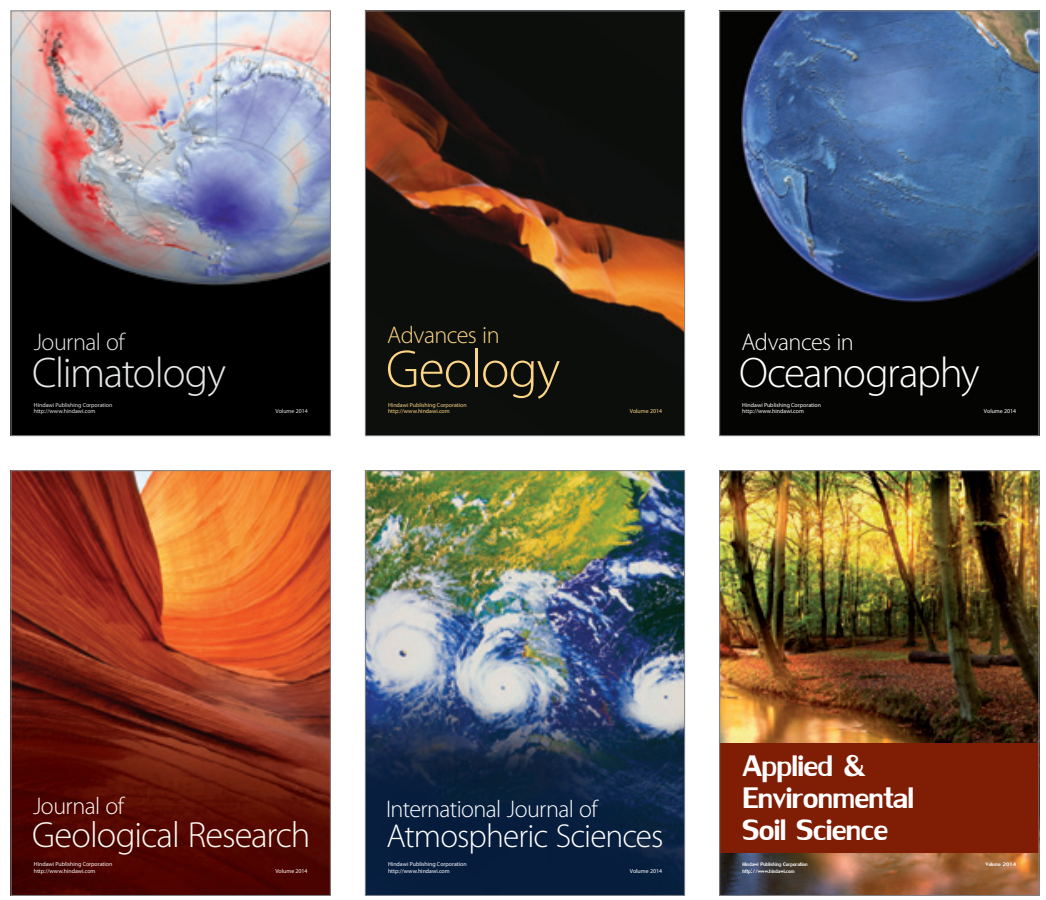
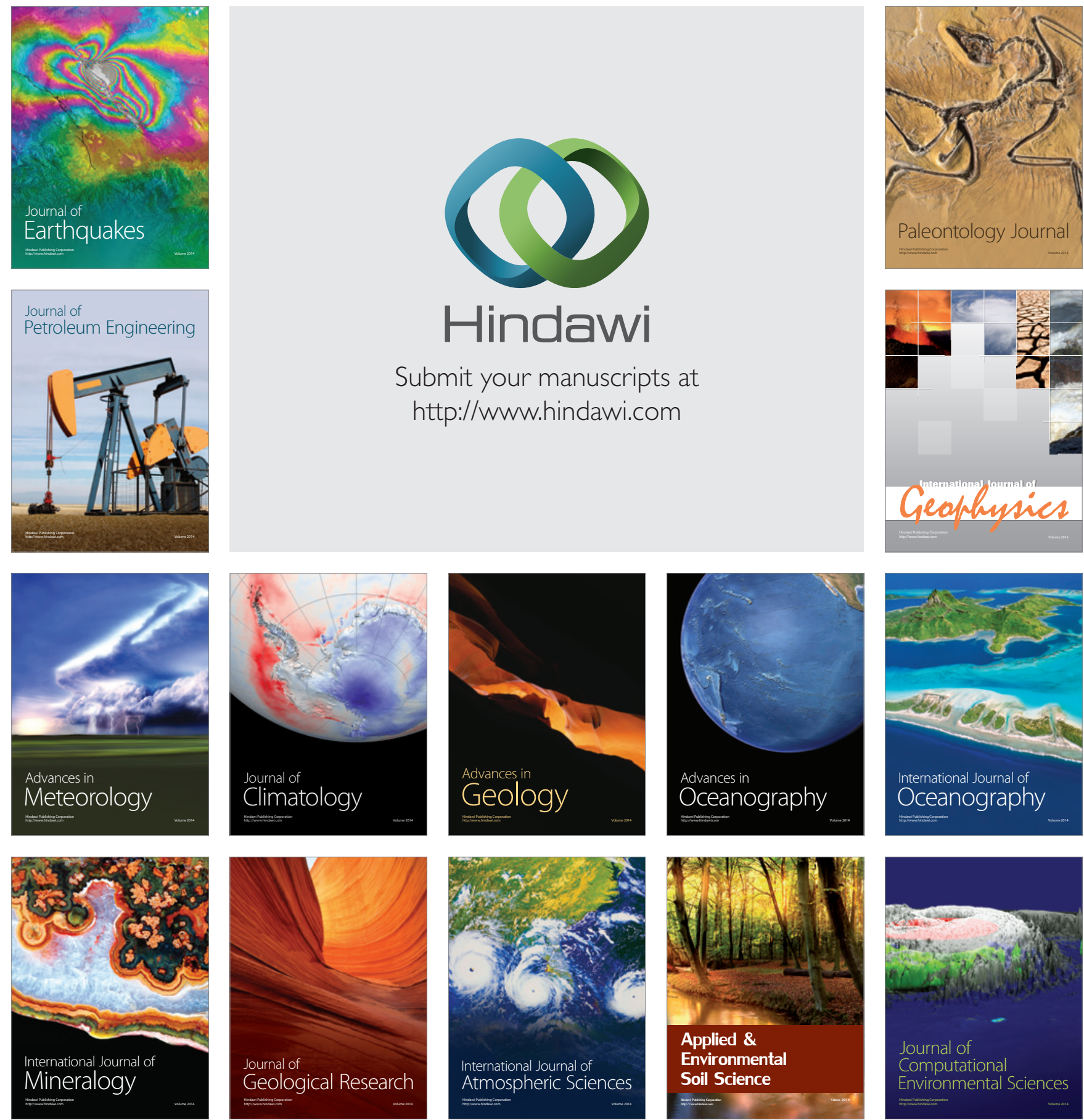